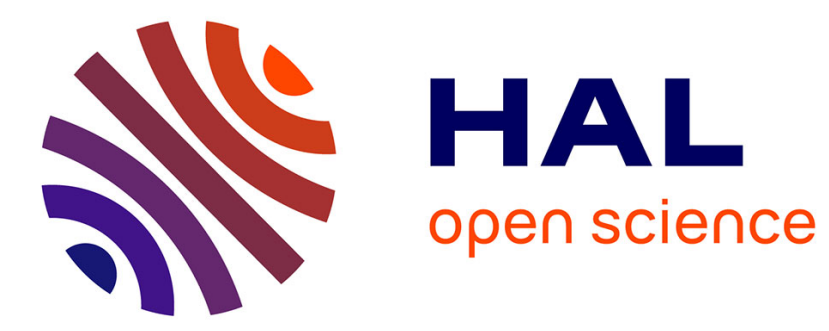

\title{
Fragment Linking Strategies for Structure-Based Drug Design
}

\author{
Alexandre Bancet, Claire Raingeval, Thierry Lomberget, Marc Le Borgne, \\ Jean-François Guichou, Isabelle Krimm
}

\section{- To cite this version:}

Alexandre Bancet, Claire Raingeval, Thierry Lomberget, Marc Le Borgne, Jean-François Guichou, et al.. Fragment Linking Strategies for Structure-Based Drug Design. Journal of Medicinal Chemistry, 2020, 63 (20), pp.11420-11435. 10.1021/acs.jmedchem.0c00242 . hal-02909120

\section{HAL Id: hal-02909120 \\ https://hal.science/hal-02909120}

Submitted on 8 Dec 2020

HAL is a multi-disciplinary open access archive for the deposit and dissemination of scientific research documents, whether they are published or not. The documents may come from teaching and research institutions in France or abroad, or from public or private research centers.
L'archive ouverte pluridisciplinaire HAL, est destinée au dépôt et à la diffusion de documents scientifiques de niveau recherche, publiés ou non, émanant des établissements d'enseignement et de recherche français ou étrangers, des laboratoires publics ou privés. 
This document is confidential and is proprietary to the American Chemical Society and its authors. Do not copy or disclose without written permission. If you have received this item in error, notify the sender and delete all copies.

\section{Fragment linking strategies for structure-based drug design}

\begin{tabular}{|r|l|}
\hline Journal: & Journal of Medicinal Chemistry \\
\hline Manuscript ID & jm-2020-00242x.R2 \\
\hline Danuscript Type: & Perspective \\
\hline Author: & 13-Jun-2020 \\
\hline & $\begin{array}{l}\text { Complete List of Authors: } \\
\text { Rancet, Alexandre; University of Lyon } \\
\text { Raingeval, Claire; University of Lyon } \\
\text { Bioactive Molecules and Mersicinal Chemistry } \\
\text { Le Borgne, Marc; Universite Claude Bernard Lyon 1 - Domaine de } \\
\text { Rockefeller, EA 4446 B2MC } \\
\text { guichou, jean-fran\&ccedil;ois; University of Montpellier, } \\
\text { Krimm, Isabelle; Universite Claude Bernard Lyon 1, CRMN }\end{array}$ \\
\hline
\end{tabular}

\section{SCHOLARONE"}

Manuscripts 
ABSTRACT: Fragment-based drug discovery is a strategy widely used both in academia and pharmaceutical companies, to generate smallmolecule protein inhibitors and drug
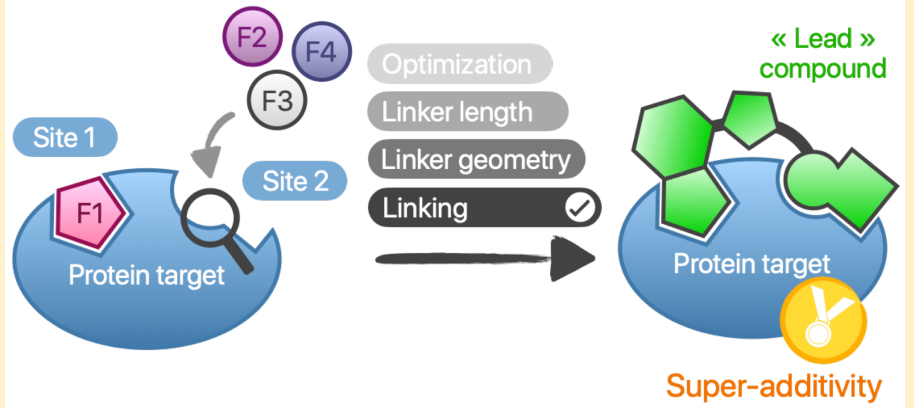
candidates. Among the approaches reported in the literature (growing, linking and merging), the linking approach theoretically offers the opportunity to rapidly gain in binding energy. Nevertheless, this approach is poorly represented when considering the compounds currently in clinical trials. Here, we report an exhaustive view of the cases published so far in the literature, together with the methods used to identify the two initial fragments either simultaneously or successively. We review the different types of linkers published and discuss how these linkers are designed to obtain the lead compound. Mixing merging and linking methods, 
where the linker is duplicated from a known inhibitor appears as an interesting strategy. To reach super-additivity, we propose to grow one of the fragments in order to minimize the distance between the two binders, and then link the resulting compounds using flexible alkyl-derived linkers.

\section{INTRODUCTION}

Fragment-based drug discovery (FBDD) has been acknowledged in the past two decades as a powerful tool for rational design of drug leads. ${ }^{1-6}$ The first step of the FBDD process consists in the identification of fragments that weakly bind the target protein, typically in the micromolar to millimolar affinity range. Fragments are defined as low molecular weight $(<300 \mathrm{~g} / \mathrm{mol})$ and highly soluble organic molecules. Jhoti and co-workers ${ }^{7}$ proposed a rule of three to describe the physicochemical properties of the fragments, by analogy to Lipinski's rule of five. Due to the weak affinity of the fragments for their targets, biophysical techniques sensitive towards micromolar to millimolar affinities are required to identify hits; among them Nuclear Magnetic Resonance (NMR), X-ray crystallography and Surface Plasmon Resonance (SPR) are the most widely used. ${ }^{1,2,3,5}$ In a second, iterative and time-consuming step, the fragments that form high quality interactions are optimized into lead compounds exhibiting higher affinity and selectivity, through the so-called fragment growing, fragment merging or fragment linking strategies. As we will see in the examples discussed below, fragment linking may include growing or merging steps and distinguish between the three strategies may be ambiguous. Vemurafenib, ${ }^{8}$ the first drug originating from a fragment screen, was approved in 2011 by the Food and Drug Administration (FDA), and two other drugs (venetoclax ${ }^{9}$ and erdafitinib ${ }^{10}$ ) were approved in 2016 and 2019, respectively. Vemurafenib and erdafitinib exemplify the growing approach, while venetoclax illustrates the linking method. To have an overview of the fragment-based development of therapeutic compounds, we report in Table 1 the 43 small-molecules currently in clinical trials (phase 1,2 and 3) and the 3 FDA-approved compounds. We indicate the therapeutic target and the fragment-based strategy used. As reported in Table 1, most of the compounds in the clinic were obtained using the growing approach, where chemical groups are progressively added to the fragment hit to maximize the favorable interactions with the binding site residues. In some cases, fragment hits can be merged, as reported for 
the induced myeloid leukemia cell differentiation protein (MCL1) (Table 1). Here, we focus on the fragment linking approach, where two fragments that bind at distinct protein pockets are linked together to obtain a new compound. While this approach theoretically represents a very attractive methodology to rapidly gain in binding affinity from the initial fragments, it faces two major challenges. First, the observation of two fragments binding simultaneously at two distinct binding pockets of a protein is not systematic. This is related to the non-equivalence of the corresponding hot-spots in the binding pockets. As reported in Table 2, a second screening to identify fragments capable to bind in the second pocket may be necessary. In addition, the fragments do not necessarily bind to the protein in suitable positions for linking. The second challenge remains the design of a linker that will maintain the protein-fragment interactions. Fesik and co-workers ${ }^{11,12}$ first successfully used the fragment linking methodology through their Structure-Activity Relationships (SAR) by NMR approach (Figure 1), with the generation of nanomolar compounds for the FK506-binding protein (FKBP), a prolyl isomerase belonging to the immunophilin family. Due to its binding properties to the immunosuppressant molecule FK506, FKBP is a target for neurodegenerative disorders.

In 2011, Whittaker and colleagues ${ }^{13}$ reviewed examples where the fragment linking approach was used and focused their discussion on the super-additivity concept. The concept of super-additivity (also called positive cooperativity) was defined by Jencks. ${ }^{14}$ It stipulates that the affinity of the linked compound should be greater that the affinity resulting from the addition of the binding energies of the two fragments. The super-additivity energetic term includes changes in translational and rotational entropy, loss of binding energy due to the linker and change in binding orientation of the two fragments. When the orientation of the fragments is not disturbed, changes in translational and rotational entropy dominate. Whittaker and colleagues ${ }^{13}$ proposed that one key criterion to achieve super-additivity is to maintain the binding modes of the initial fragments. To be successful, linking should therefore involve one fragment that interacts with the protein through polar interactions and a second fragment that interacts via van der Waals interactions, as the latter will be more tolerant to changes in binding mode. This statement will be further discussed later in the perspective.

Here we have reviewed, to the best of our knowledge, all cases where the fragment linking approach has been used, through 2018. To our point of view, the first step that consists in the identification of two 
fragment hits is not straightforward. As we report below, two fragments bound in two distinct protein pockets were directly identified in 22 cases out of 39 , while 17 cases required the conduction of two successive screens. Once two fragments have been identified, the main challenge is the design of the linker, in particular when the distance between the two fragments is large (> $3 \AA$ ). One possibility consists in reducing the distance between the two fragments. To do so, one of the two fragments is selected and a growing approach is applied until the distance is close to $3 \AA$. Regarding the chemical structure of the linker, simple linkers such as alkyl of different lengths are widely used. More sophisticated linkers include functional groups, which may be utilized to fit particular geometries such as $90^{\circ}$ bends required to conserve the positions and orientations of the fragments. Such functionalized linkers also enable the addition of interactions between the designed compound and the protein.

The article is organized as follows. First, we summarize the methods used for the identification of the two fragments that will be further linked. This includes successive identification as well as simultaneous identification of the two fragment hits. We also review the particular case of fragment dimerization. Then we discuss the second challenge of the linking process and analyze different types of linkers that have been designed to generate the new linked compounds. 


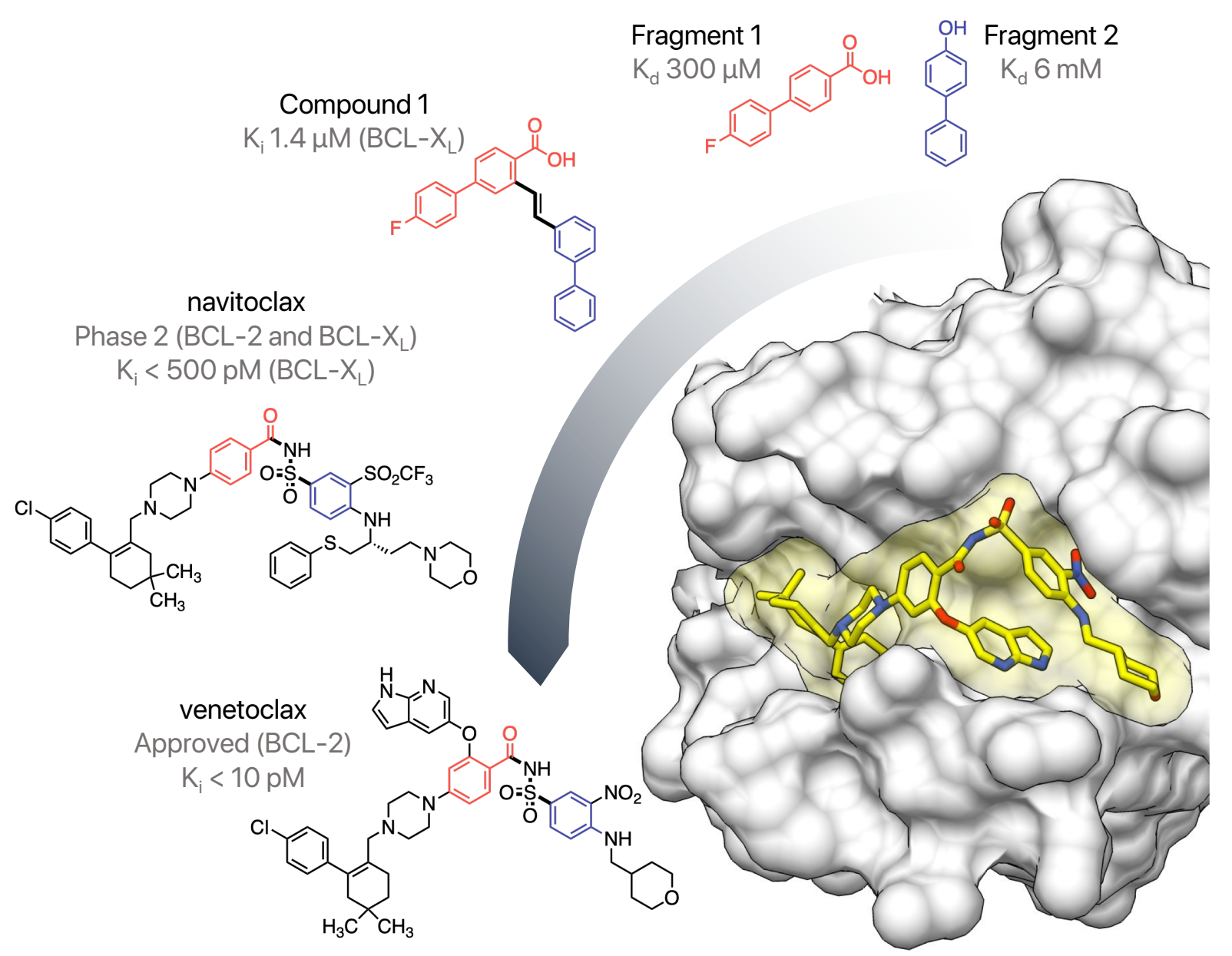

Figure 1. Fragment linking approach with venetoclax. The initial fragments discovered through "SAR by NMR" were linked with an alkene moiety. Navitoclax, exhibiting high affinity for both BCL- $X_{L}$ and BCL-2, was generated and finally, medicinal chemistry led to venetoclax, a selective BCL-2 inhibitor. The drug was first approved for use in patients with chronic lymphocytic leukemia and $17 \mathrm{p}$ deletion. 
Table 1. Fragment-based compounds in clinical trials or approved (From clinicaltrials.gov, 2020 January)

\begin{tabular}{|c|c|c|c|}
\hline $\begin{array}{l}\text { Drug }^{\bullet} \\
\text { Biological target }\end{array}$ & Company & Status & $\begin{array}{c}\text { Initial fragment } \\
\text { strategy }\end{array}$ \\
\hline $\begin{array}{l}\text { Erdafitinib } \\
\text { FGFR }\end{array}$ & Johnson \& Johnson / Astex & Approved & Growing \\
\hline $\begin{array}{l}\text { Vemurafenib } \\
\text { BRAF-V600E }\end{array}$ & Plexxikon & Approved & Growing \\
\hline $\begin{array}{l}\text { Venetoclax } \\
\text { BCL-2 }\end{array}$ & AbbVie / Genentech, Inc. & Approved & Linking \\
\hline $\begin{array}{l}\text { Asciminib } \\
B C R-A B L\end{array}$ & Novartis & Phase 3 & Growing \\
\hline $\begin{array}{l}\text { PLX3397 } \\
\text { CSF1R, KIT, FLT3 }\end{array}$ & Plexxikon & Phase 3 & Growing \\
\hline $\begin{array}{l}\text { Verubecestat } \\
\text { BACE1 }\end{array}$ & Merck & Phase 3 & Growing \\
\hline $\begin{array}{l}\text { AZD3293 } \\
\text { BACE1 }\end{array}$ & Astex / AstraZeneca / Lilly & Phase $2 / 3$ & Growing \\
\hline
\end{tabular}

ABT-737

$B C L-2 \& B C L-X L$

AbbVie

Phase 2

Linking

AT7519

CDK1, CDK2, CDK4, CDK5

Astex

Phase 2

Growing

\& CDK9

AT9283

Aurora \& JAK2

Astex

Phase 2

Growing

AUY922

HSP9O

Novartis, Vernalis

Phase 2

Growing

AZD5363

AKT

AstraZeneca / Astex

Phase 2

Growing

CPI-0610

BET

Constellation

Phase 2

Growing

eFT508

MNK1 \& MNK2

eFFECTOR

Phase 2

Growing

Indeglitazar

PPAR agonist

Plexxikon

Phase 2

Growing

LY3202626

Lilly

Phase 2

Growing 


\section{BACE1}

LY517717

FXa

Lilly / Protherics

Phase 2

Growing

Navitoclax

BCL-2 \& BCL-X $\mathrm{L}$

AbbVie

Phase 2

Linking

Onalespib

HSP9O

Astex

Phase 2

Growing

PF-06650833

IRAK4

Pfizer

Phase 2

Growing

PF-06835919

KHK

Pfizer

Phase 2

Growing

AMG 510

KRAS

Amgen

Phase 1/2

Growing

ASTX029

ERK1 \& ERK2

Astex

Phase 1/2

Growing

ASTX660

XIAP \& CIAP1

Astex

Phase 1/2

Growing

LY2886721

BACE1

Lilly

Phase 1/2

Growing

MAK683

PRC2

Novartis

Phase $1 / 2$

Growing

ABBV-075

BRD2

AbbVie

Phase 1

Growing

ABT-518

MMP2 \& MMP9

AbbVie

Phase 1

Linking

AT13148

AKT, S6K1 \& ROCK

Astex

Phase 1

Growing

AZD3839

BACE1

AstraZeneca / Astex

Phase 1

Growing

AZD5099

Bacterial topoisomerase II

AstraZeneca

Phase 1

Growing

AZD5991

MCL1

AstraZeneca

Phase 1

Merging

BCL201

BCL-2

Vernalis / Servier / Novartis

Phase 1

Growing

BI691751

LTA4H

Boehringer Ingelheim

Phase 1

Growing

ETC-1907206

MNK1 \& MNK2

EDDC / A*STAR Research

Entities

Phase 1

Growing 


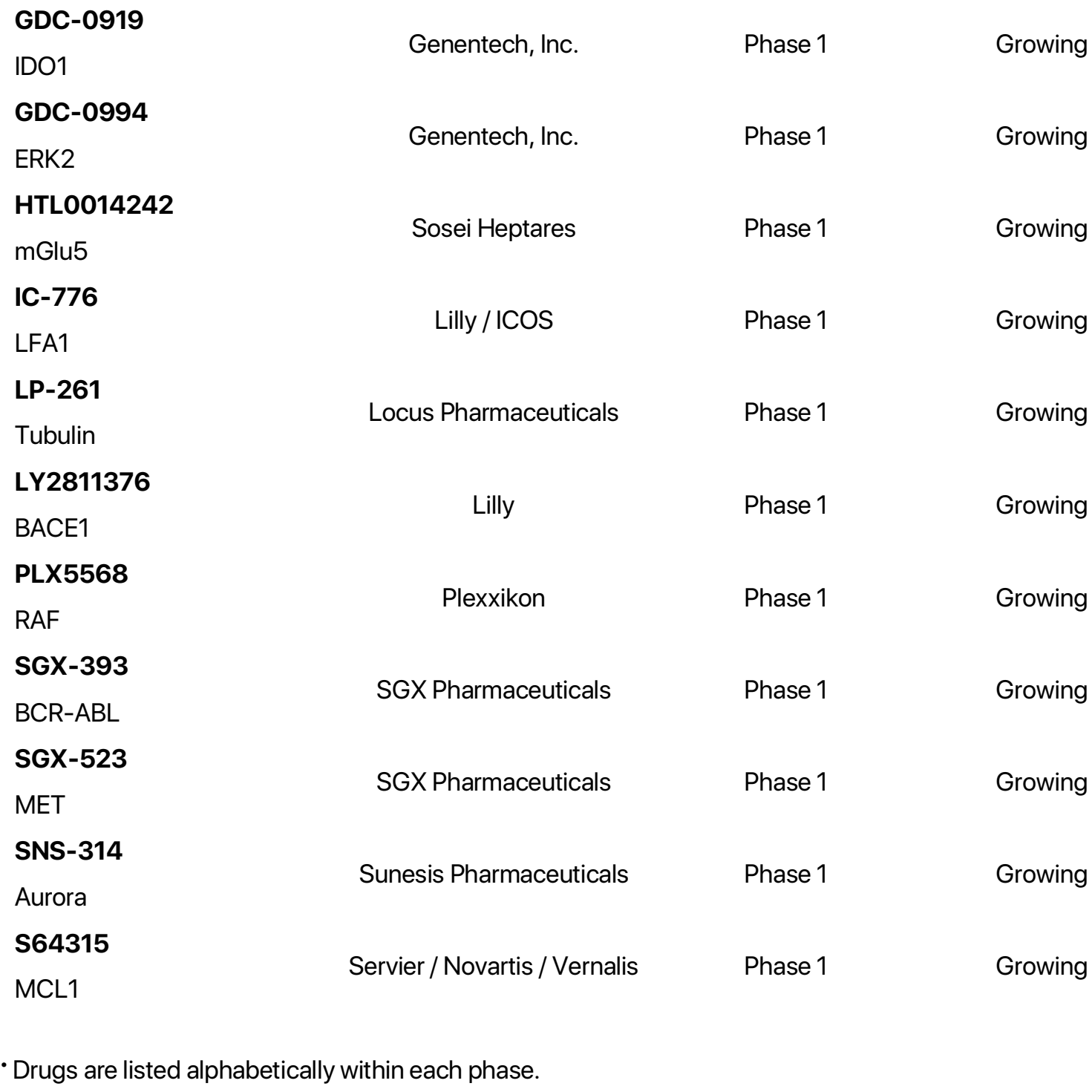




\section{SECOND-SITE SCREENING FOR IDENTIFICATION OF A SECOND FRAGMENT}

As widely reported in the literature, it can be necessary to perform a second screening to identify a fragment bound in another binding site (Table 2). To do so, it may be worth occupying the first site to block its entry. This is partly due to the fact that the fragments typically bind a preferred hot-spot on the protein surface. Moreover, the detection of second-site ligands is generally more difficult because these fragments tend to have a weaker affinity for the target than the first-site ligands. We present below six different strategies that have been used in the literature to identify second-site fragments. The strategies are illustrated in Figure 2.

2.1. Screening using protein-observed NMR or "SAR by NMR". NMR is an established technique for fragment screening and is particularly attractive for linking strategies. In protein-detected experiments, the protein is typically ${ }^{15} \mathrm{~N}$ or ${ }^{13} \mathrm{C}$ labeled and two-dimensional heteronuclear NMR experiments are used to observe the protein NMR peak modifications upon ligand addition. Most of the published cases deal with small to medium-sized proteins, such as protein domains, for which the NMR assignment is not a difficult task. Fesik and collaborators ${ }^{11,12}$ at Abbott established the "SAR by NMR" approach to design a potent inhibitor of the FKBP binding domain. Two fragments bound in two pockets were identified from the NMR experiments and a linker was elaborated using structural data from ${ }^{15} \mathrm{~N}$ ${ }^{13} \mathrm{C}$-filtered protein-ligand Nuclear Overhauser Effect (NOE) (Table 2, entry 1). With the same approach, a linked compound was designed for the stromelysin protein (Table 2, entry 2) ${ }^{15}$ Navitoclax, the orally active anti-cancer drug, ${ }^{16-18}$ which led to venetoclax, ${ }^{9}$ was discovered using the SAR by NMR strategy (Figure 1). In another study, the group of Hadjuk ${ }^{19}$ designed a highly potent B-cell lymphoma 2 (BCL-2) inhibitor using a library of 17,000 compounds for a first screen and a small library of 70 compounds for a second screen (Table 2, entry 3). Another specific inhibitor of B-cell lymphoma-extralarge $\left(\mathrm{BCL}-\mathrm{X}_{\mathrm{L}}\right)$ was designed by Souers and colleagues. ${ }^{20}$ In this case, the first site was blocked using a compound derived from High-Throughput Screening (HTS) and medicinal chemistry. 875 fragments were screened to identify a second-site ligand that could be linked to the first-site compound (Table 2, entry 4). The fragment linking approach was also successfully applied to the heat shock protein 90 
(HSP90) (Table 2, entry 5) ${ }^{21}$ and to the protein tyrosine phosphatase-1B (PTP1B) (Table 2, entries 6, 7)..$^{22,23}$

2.2. Screening using ligand-observed ${ }^{1}$ H NMR. Ligand-observed NMR offers different opportunities for identifying second-site ligands that bind at the vicinity of a first-site ligand. By contrast to the "SAR by NMR" approach, ligand-observed experiments are performed for medium-size to very large proteins. One strategy is to use 2D Nuclear Overhauser Effect Spectroscopy (NOESY) experiments that allow the identification of compounds that bind near $(\sim 5 \AA)$ a first-site ligand through the observation of InterLigand NOEs (ILOEs). ${ }^{24-26}$ It is possible to modify the first-site ligand through the addition of methyl group(s), allowing the generation of a suitable NOESY probe for the observation of strong NOESY cross peaks in a spectral region with little overlap. Such experiments, referred as "SAR by ILOE", have been used for the design of protein-protein interaction inhibitors for the targets BCL- $\mathrm{X}_{\mathrm{L}}$ and MCL1 (Table 2, entry 8). ${ }^{27,28}$ In addition to the identification of second-site ligands, the ILOE experiment can be used to assess the orientation of the second-site ligand relative to the first-site ligand, as shown by the group of Abell for the Mycobacterium turberculosis pantothenate synthetase (PS) (Table 2, entry 9) ${ }^{29}$ and confirm previously results obtained by X-Ray crystallography. ${ }^{30}$

Another strategy is to use paramagnetic labeling, ${ }^{31,32}$ taking advantage of the paramagnetic enhancement (PRE) obtained thanks to the paramagnetic labeling of a first-site ligand. Typically, a 2,2,6,6tetramethylpiperidin-1-oxyl (TEMPO) moiety is used. The transverse relaxation rate of the protons located within a radius of $\sim 10 \AA$ of the first-site ligand is drastically enhanced, which significantly reduces the NMR signal intensities. ${ }^{33,34}$ This approach has been successfully applied for the development of nanomolar E-selectin antagonists by Ernst and co-workers ${ }^{35}$ (Table 2, entry 10).

2.3. Screening using ligand-observed ${ }^{19}$ F NMR. ${ }^{19} \mathrm{~F}$ NMR spectroscopy is another tool for fragment screening, with the possibility to screen large mixtures of more than 20 fragments, taken advantage of the chemical shift dispersion of the ${ }^{19} \mathrm{~F}$ nucleus. ${ }^{19} \mathrm{~F}$ NMR is also used to search for second-site ligands, as exemplified for inhibitors of the Alzheimer target beta-secretase 1 (BACE1) (Table 2, entry 11). ${ }^{36,37}$ 
2.5. Second-site ligand following tethering-based first-site ligand. Wells and colleagues ${ }^{40}$ have developed an alternative strategy to identify fragments that bind to proteins, using a cysteine residue that can form a disulfide bond with disulfide containing fragments. The disulfide bond of the fragments that display affinity for the protein are entropically stabilized while the other disulfide bonds can be easily reduced. Tethered compounds were then recognized by Mass Spectrometry (MS). The approach was used to generate a novel non-peptidic inhibitor of caspase 3 (Table 2, entry 14 ). ${ }^{41}$ The methodology was also used by Raimundo and co-workers. ${ }^{42}$ They developed a potent small-molecule inhibitor of interleukin 2 (IL2) starting from a library of 7,000 disulphide-containing fragments (Table 2, entry 15).

2.6. Second-site ligand screening with focused libraries. To identify second-site ligands, another strategy is to screen a fragment library that is chemically oriented to bind a particular protein-binding pocket. For example, the group of Hudson ${ }^{43}$ screened a focused library of 450 fragments containing acids to find hits able to bind to the negatively charged region of the LDHA protein. The hit fragment was then linked to another fragment bound in the adenine region of the cofactor nicotinamide adenine 
dinucleotide (NADH) (Table 2, entry 16). Another example was published by Gaul and co-workers ${ }^{44}$ regarding disruptor of telomeric silencing 1-like (DOT1L), a potential therapeutic target involved in leukemias. The first site was blocked with a DOT1L inhibitor to search for fragments that bind in the cofactor S-adenosylmethionine (SAM) pocket using NMR (Table 2, entry 17). In parallel, a focused virtual screening followed by a biochemical screen was performed for the cofactor pocket. The NMR and biochemical hits were further studied by X-ray crystallography. Modeling studies suggested to link a fragment and a second-site binder, which led to a new structure with low nanomolar affinity. 
Table 2. Fragment linking by second-site screen.
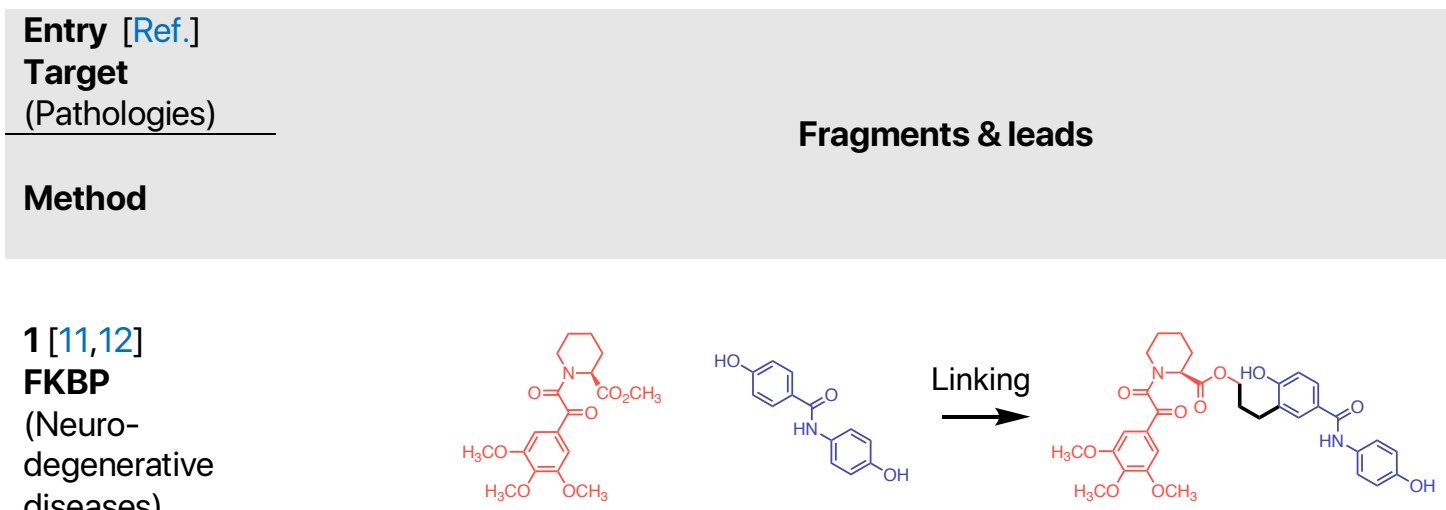

$K_{d}=2 \mu M \quad K_{d}=100 \mu M$

$\mathrm{K}_{\mathrm{d}}=49 \mathrm{nM}$

2[15]

MMP3

(Cardiovascular diseases)

NMR

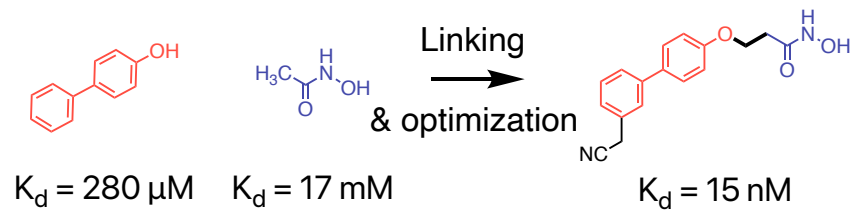

3 [19]

BCL-2

(Cancer \& autoimmune diseases)

NMR

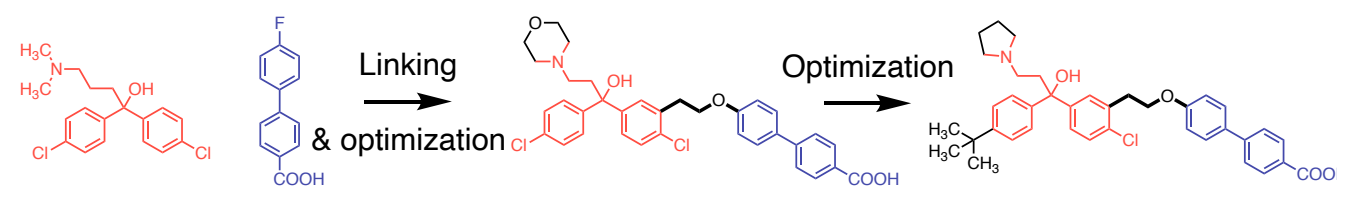

$K_{d}=20 \mu M \quad K_{d}=300 \mu M$

$\mathrm{K}_{\mathrm{d}}=220 \mathrm{nM}$

$\mathrm{K}_{\mathrm{d}}=40 \mathrm{nM}$

4 [20]

BCL-XL

(Cancer \& autoimmune diseases)

NMR
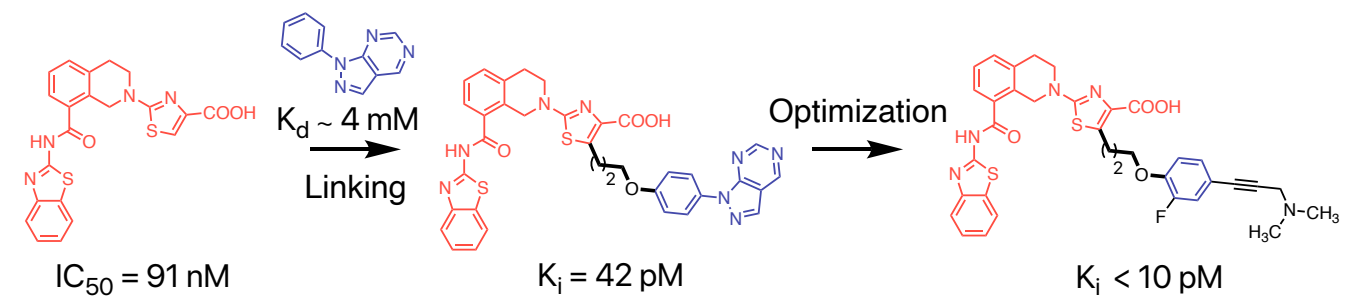

$\mathrm{K}_{\mathrm{i}}=42 \mathrm{pM}$

$\mathrm{K}_{\mathrm{i}}<10 \mathrm{pM}$

5 [21]

HSP9O

(Cancer \&

neuro-

degenerative

diseases)

NMR

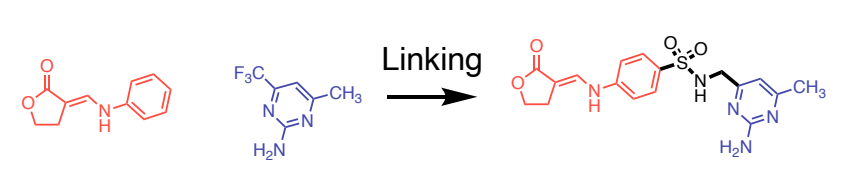

$K_{d}=150 \mu M \quad K_{d}=20 \mu M$

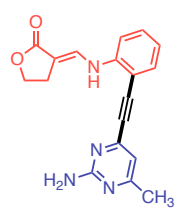

$\mathrm{K}_{\mathrm{i}}=1.9 \mu \mathrm{M}$ Closed state
$\mathrm{K}_{\mathrm{i}}=4 \mu \mathrm{M}$

Open state 
6 [22]

PTP1B

(Obesity,

diabetes and

cardiovascular

diseases)

NMR

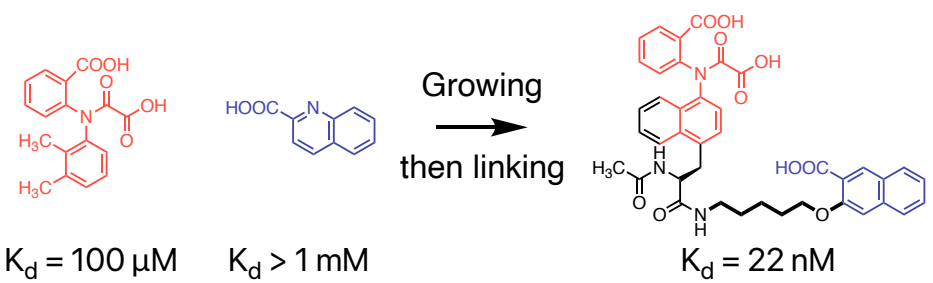

7 [23]

PTP1B

(Obesity,

diabetes and

cardiovascular

diseases)

NMR
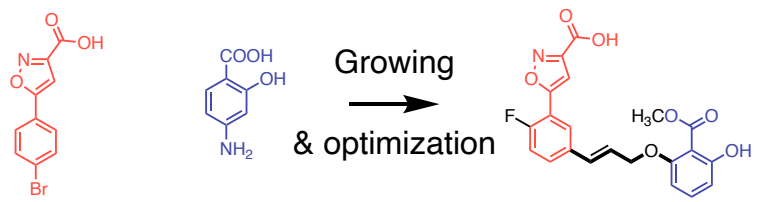

$8[27,28]$

BCL-X, MCL1

(Cancer \& autoimmune diseases)

$\mathrm{K}_{\mathrm{d}}=800 \mu \mathrm{M} \mathrm{K}_{\mathrm{d}}=1.2 \mathrm{mM}$

$$
\mathrm{K}_{\mathrm{d}}=7 \mu \mathrm{M}
$$

NMR

$$
\mathrm{K}_{\mathrm{d}}=378.4 \mu \mathrm{M}
$$

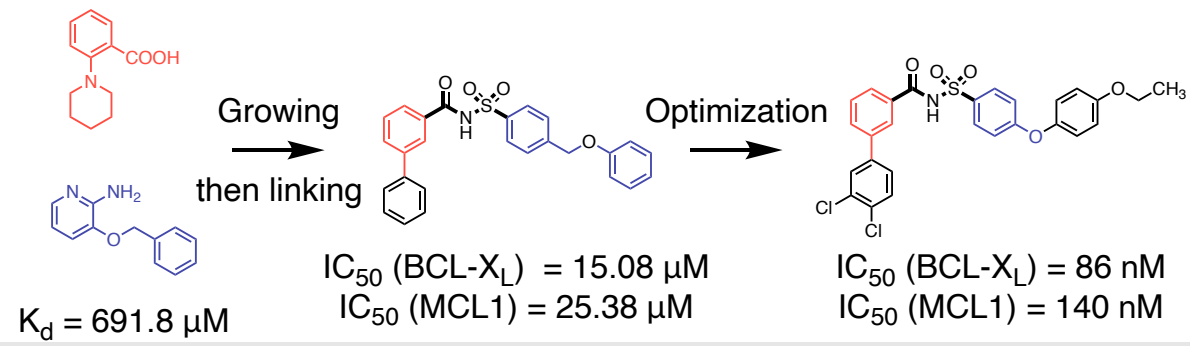

$9[29,30]$

PS

(Infectious

diseases)

X-Ray \& NMR
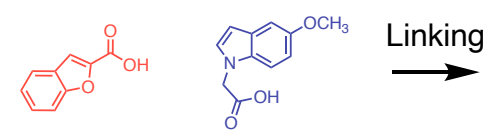

$\mathrm{K}_{\mathrm{d}}=1 \mathrm{mM} \quad \mathrm{K}_{\mathrm{d}}=500 \mu \mathrm{M}$

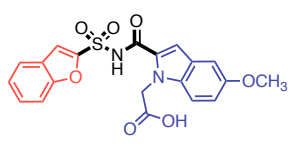

$\mathrm{K}_{\mathrm{d}}=1.8 \mu \mathrm{M}$
10 [35]

E-selectin (Cardiovascular diseases)

NMR

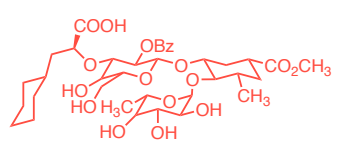

$\mathrm{K}_{\mathrm{d}}=1.9 \mu \mathrm{M}$

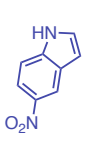

$\mathrm{K}_{\mathrm{d}}$ not reported

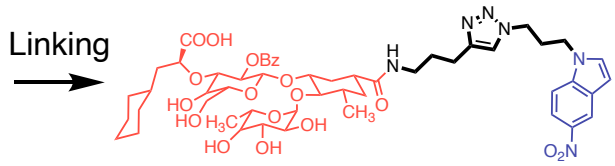

$\mathrm{K}_{\mathrm{d}}=30 \mathrm{nM}$

$11[36,37]$

BACE1

(Neurodegenerative diseases)

NMR

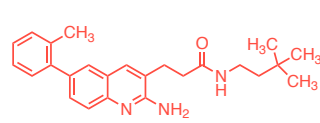

$K_{d}=140 n M$

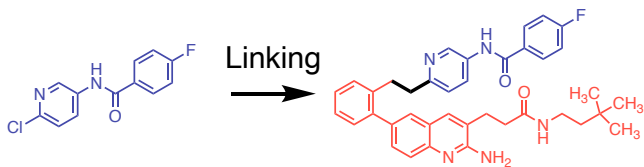

$\mathrm{K}_{\mathrm{d}}=114 \mu \mathrm{M}$ 
12 [38]

HSP9O

(Cancer \&

neuro-

degenerative

diseases)

NMR

13 [39]

LDHA

(Cancer)

X-Ray \& NMR
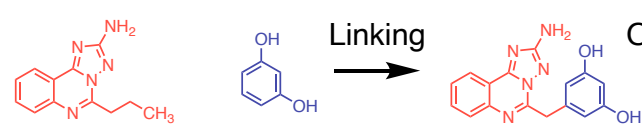

$\mathrm{K}_{\mathrm{i}}=32 \mu \mathrm{M} \quad$ Resorcinol

$K_{i}=6.1 \mu M$

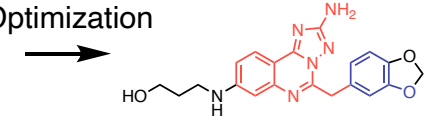

14 [41]

\section{CASP3}

(Neurodegenerative diseases) Tethering

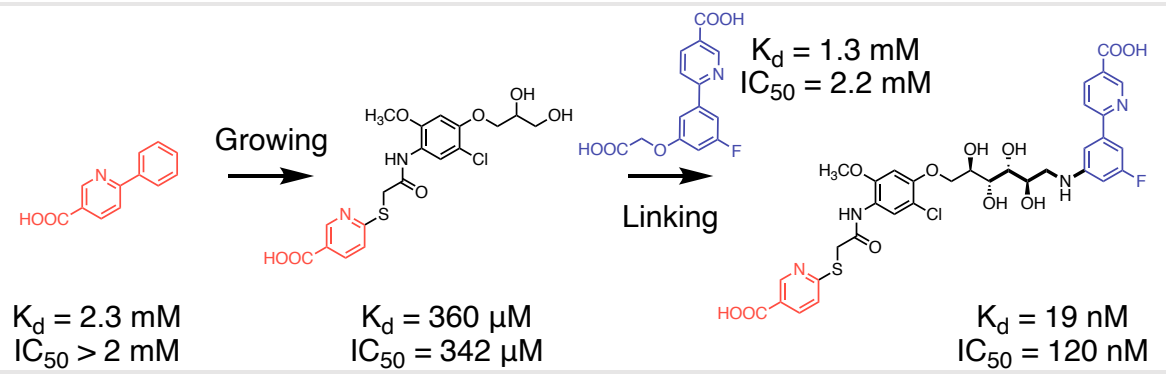

15 [42]

IL2

(Autoimmune diseases)

Tethering
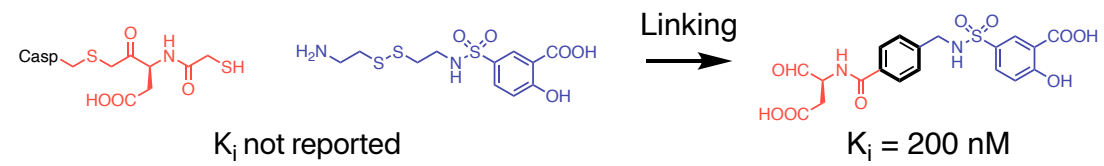

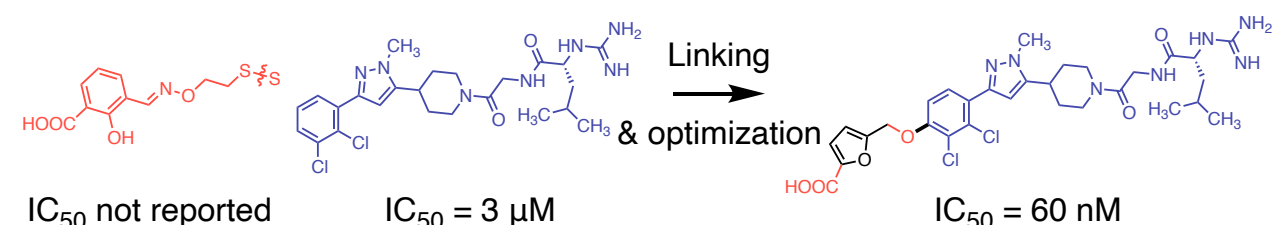

$\mathrm{IC}_{50}$ not reported

$\mathrm{IC}_{50}=3 \mu \mathrm{M}$
16 [43]

LDHA

(Cancer)

NMR \& SPR

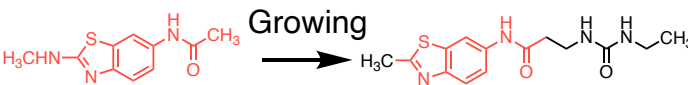

$$
\begin{aligned}
& \begin{array}{r}
\mathrm{K}_{\mathrm{d}}=770 \mu \mathrm{M} \\
\mathrm{C}_{50}>500 \mu \mathrm{M}
\end{array} \\
& \mathrm{K}_{\mathrm{d}}=160 \mu \mathrm{M} \\
& \mathrm{IC}_{50}>500 \mu \mathrm{M}
\end{aligned}
$$
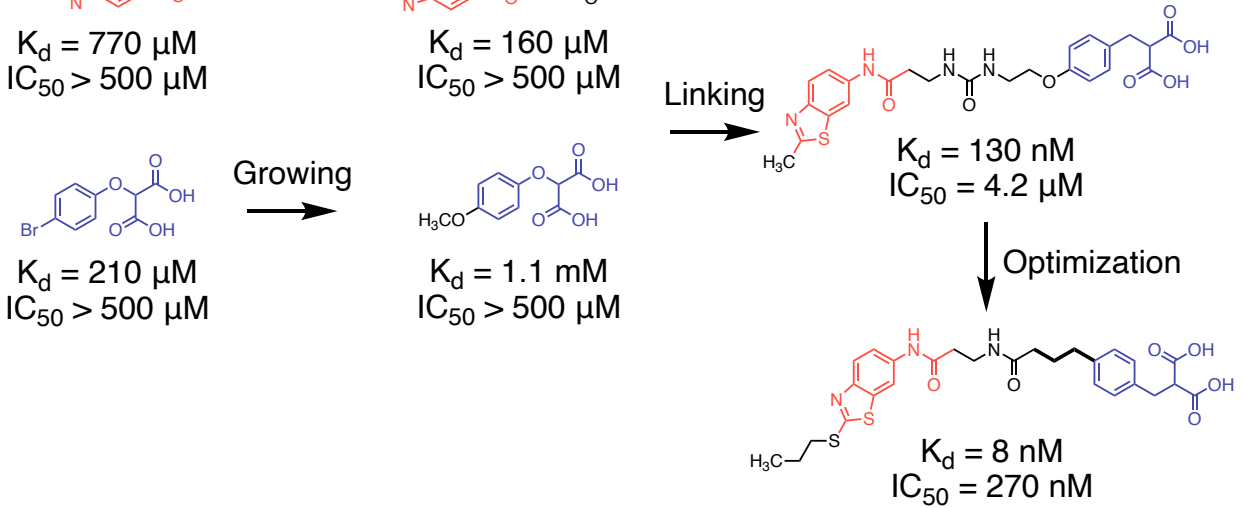
17 [44]

DOT1L

(Cancer)

Bioassay, X-

Ray \& NMR
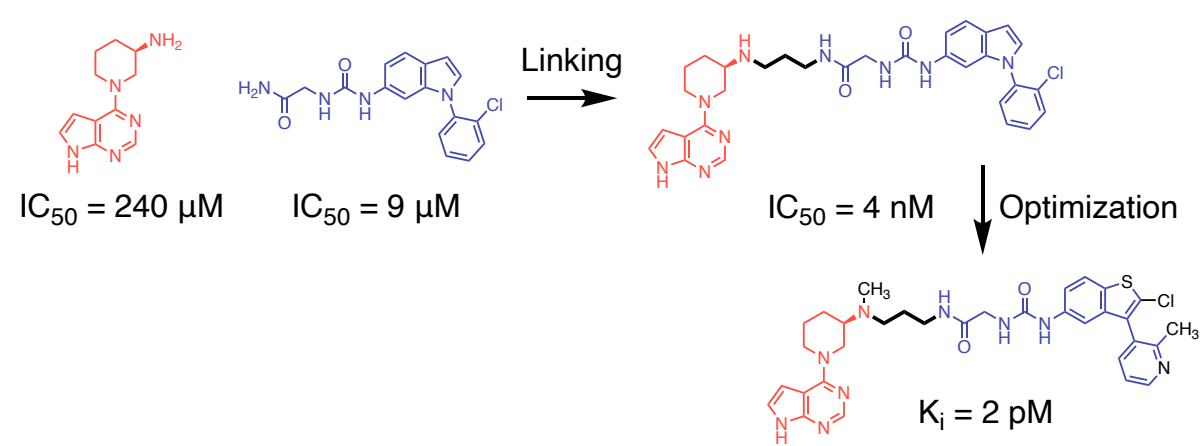
A

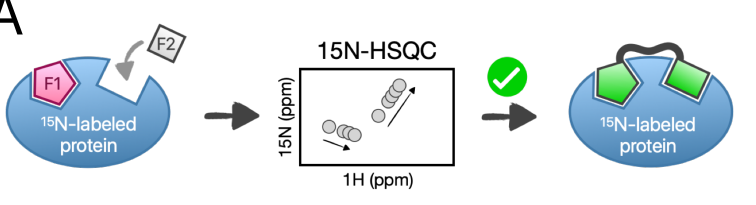

$\mathrm{B}$

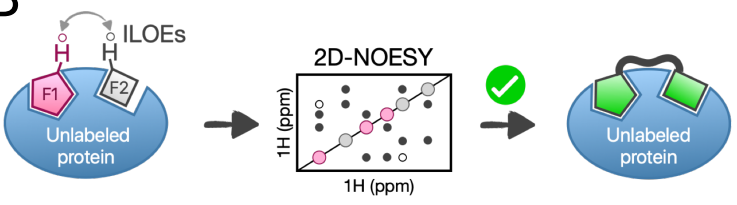

C
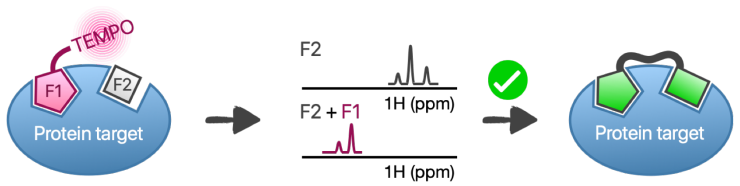

$\mathrm{D}$

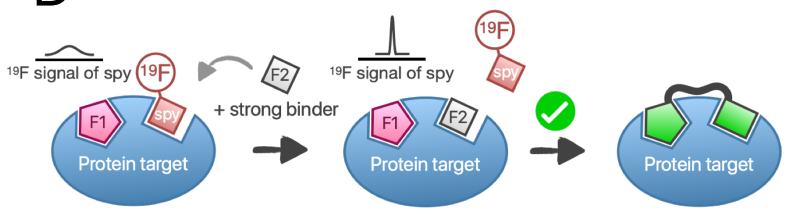

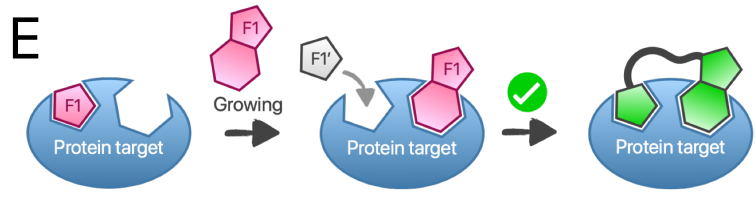

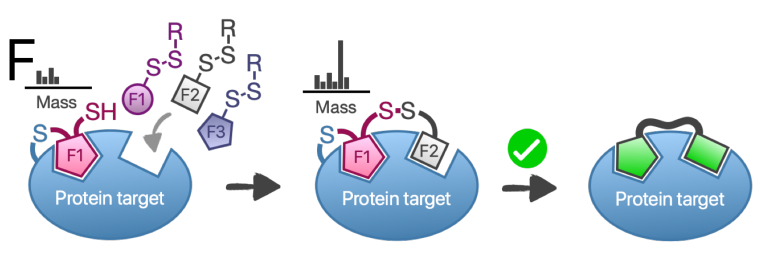

G

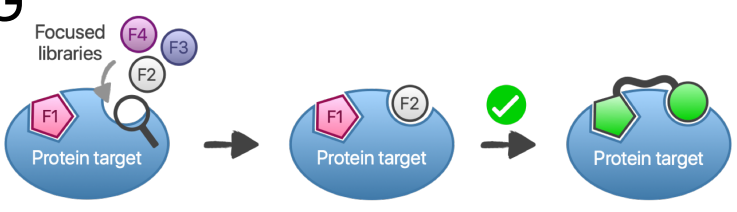

Figure 2. Schematic representation of methods for second-site screening for identification of a second fragment hit. A) Screening using protein-observed NMR or "SAR by NMR". A first hit (pink) is identified through chemical shift perturbations of a $2 \mathrm{D} 15 \mathrm{~N}$ or $13 \mathrm{C}$ labeled protein spectrum. Chemical shifts perturbations observed in a second site of the protein (grey) indicate the binding of a second fragment. B) Screening using ligand-observed ${ }^{1} \mathrm{H}$ NMR: the ILOE method. A first fragment hit is used as a spy to discover a second fragment hit that binds in the vicinity of the first binder (distances $(\sim 5 \AA)$, through NOESY correlations observed between the two adjacent ligands. C) Screening using ligand-observed ${ }^{1} \mathrm{H}$ NMR : the PRE method. A first fragment hit is used as a spy labeled with paramagnetic tag using a 2,2,6,6-tetramethylpiperidin-1-oxyl (TEMPO) moiety. The second fragment hit displays reduced NMR signal intensities due its proximity to the TEMPO moiety. D) Screening using ligand-observed ${ }^{19} \mathrm{~F}$ NMR. A spy molecule is labeled with a fluorine tag to identify fragments that competitively bind with the spy molecule. E) Second-site ligand resulting from elaboration of a firstsite ligand. Fragment growing generates a new ligand that bind in a distinct pocket. F) Second-site ligand 
following tethering-based first-site ligand. A first fragment is covalently bound to the protein through a cysteine residue. A second cysteine residue is used to form a disulfide bond with disulfide containing fragments. Tethered compounds are identified by Mass Spectrometry. G) Second-site ligand screening with focused libraries. When the nature of a second pocket is known, a focused library can be used to identify a second-site binder. 


\section{DIRECT IDENTIFICATION OF FRAGMENTS BOUND TO TWO DISTINCT BINDING}

\section{SITES}

When techniques such as X-ray crystallography, NMR or virtual screening are used, the identification of two fragments that bind in two distinct sites can be a direct outcome of the screening process. As discussed below, additional methods have also been used to identify two fragments that simultaneously bind the protein. The different strategies are summarized in Figure 3.

3.1. Screening using X-ray crystallography. X-ray crystallography is a particularly attractive technique in FBDD as it directly gives the $3 \mathrm{D}$ structure of the protein-fragment complex. Using a focused library of 80 fragments on the protein thrombin, ${ }^{45}$ Astex Therapeutics observed fragments bound to the S1 pocket of the enzyme and one compound that bound to the S2-S4 region. The X-ray structures then helped the design of a linked compound (Table 3, entry 18). The group of Yarnold ${ }^{46}$ identified, using biochemical screening followed by X-ray crystallography, fragments that bound to separate sub-sites within the ATPase pocket of HSP90 (Table 3, entry 19). In another example, Guichou and colleagues ${ }^{47}$ used computational screening of 34,409 fragments to identify fragments of the cyclophilin D (CYPD) active site as well as the gatekeeper pocket. Fourteen X-ray structures were obtained, showing four fragments bound to the catalytic site of the protein while five fragments were observed in the gatekeeper pocket (Table 3, entry 20). Using a thermal shift assay followed by X-ray crystallography, Barral and co-workers ${ }^{48,49}$ identified 3 compounds that bind near the SAdenosylmethionine (AdoMet) binding pocket of the NS5 AdoMet-dependent mRNA methyltransferase (MTase) domain, highlighting a new targetable site (Table 3, entry 21). More recently, Spring et $a l^{50-52}$ found a fragment bound at multiple sites on the protein casein kinase 2 (CK2), including a previously unreported site adjacent to the adenosine triphosphate (ATP) site. The fragment was modified to generate a compound that specifically binds the newly identified pocket and linked with ATP-site ligands (Table 3, entry 22). 
3.2 Screening using protein-observed NMR. Protein-observed NMR experiments can also be used to identify two different fragments that bind simultaneously two distinct protein pockets. The group of Fesik $^{53}$ examined 14,976 fragments of replication protein A (RPA) by NMR and found compounds that bind to two distinct sites in the basic cleft of RPA70N. X-ray structures revealed the binding modes of the fragments, suggesting a strategy for fragment optimization and linking (Table 3, entry 23).

3.3. Screening using MS. Similarly to the "SAR by NMR", a "SAR by MS" approach has been proposed. Ibis Therapeutics ${ }^{54}$ used MS to screen fragments against the 1061 region of bacterial $23 \mathrm{~S}$ ribosomal ribonucleic acid (rRNA). This process includes a first step where compounds are screened against the RNA by MS. SAR is obtained by chemical modification of the hits and MS experiments. Data obtained for structurally modified hits, for which competition or absence of competition in the MS experiments was observed, led to distant restraints between initial fragments that were then linked (Table 3 , entry 24).

3.4. Screening using biochemical assays. Biochemical assays constitute straightforward screening methods that require knowledge of the biochemical protein functions. A proof of concept of the linking strategy was reported by Green ${ }^{55}$ with biotin analogues binding avidin, illustrating the super-additivity that can be achieved with the fragment linking approach (Table 3, entry 25). Another report ${ }^{56}$ showed that the knowledge of the 3D structure of the target was not crucial. Ellman and co-workers screened at high concentration a library of oximes and a small library of di-hydroxylamine linkers against the tyrosine kinase c-SRC. They could demonstrate the utility of the method with the identification of a potent and subtype-selective inhibitor (Table 3, entry 26).

3.5. Fragment self-assembly. We have also considered fragment self-assembly as examples of fragment linking, even if no linker is designed to obtain the linked compound. The process called dynamic combinatorial chemistry (DCC) is observed in situ in the presence of a target protein. As a first example, Huc and $\mathrm{Lehn}^{57}$ reported the generation of carbonic anhydrase (CA) inhibitors by combination of aldehyde and amine moieties to in situ form imines (Table 3, entry 27). Other applications were 
3.6. Inhibitor deconstruction and reconstruction. Deconstruction of known ligands can provide a useful strategy for the reconstruction of a new compound. ${ }^{70}$ Using HTS, two compounds were identified to bind the human $N$-myristoyltransferase 1 (NMT1) protein and X-ray crystallography indicated that the molecules bind in two different pockets. ${ }^{71}$ To preclude a steric clash upon compound linking, one of the hits was deconstructed to remove the quinoline moiety (Table 3, entry 38).

The linking approach can be particularly useful to replace a part of a compound that is not suitable. For example, fragments were searched to substitute a chymase inhibitor benzothiophene moiety that produced reactive metabolites. ${ }^{72}$ Takahashi and co-workers screened one thousand fragments and identified a fragment that binds in the same pocket as the benzothiophene core. The deconstruction and reconstruction of the initial inhibitor led to a compound with improved metabolic properties (Table 3, entry 39). 
3.7. Cooperative binding. In some cases, the second binding pocket is only observed in the presence of a first ligand bound to a distinct pocket. For example, Varani and colleagues ${ }^{73}$ identified six fragments capable to bind the human immunodeficiency virus 1 (HIV-1) transactivation response RNA only in the presence of the first hit, an arginine mimetic. 
Table 3. Fragment linking by direct identification of two fragments.

\section{Entry [Ref.] \\ Target \\ (Pathologies)}

Method

18 [45]

Thrombin

(Neuro-

degenerative

diseases)

X-Ray

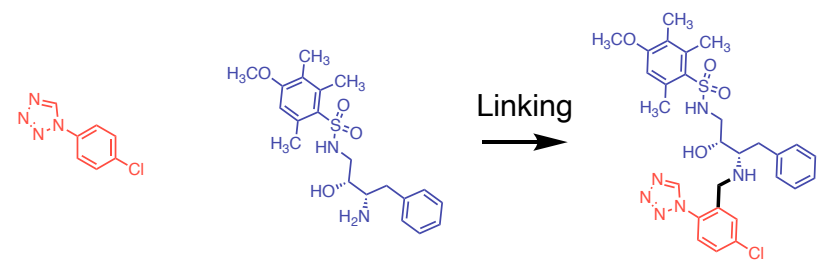

$\mathrm{IC}_{50}=330 \mu \mathrm{M}$

$\mathrm{IC}_{50}=12 \mu \mathrm{M}$

$\mathrm{IC}_{50}=1.4 \mathrm{nM}$

19 [46]

HSP9O

(Cancer \&

neuro-

degenerative

diseases)

Bioassay \& X-
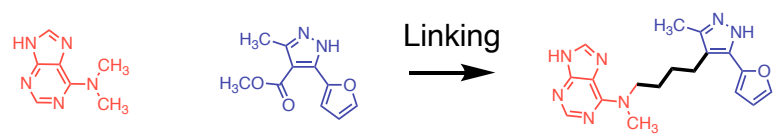

$I_{50}=1.5 \mathrm{mM} \quad I_{50}=1 \mathrm{mM}$

$\mathrm{IC}_{50}=1.5 \mu \mathrm{M}$

Ray

20 [47]

CYPD

(Viral \& neurodegenerative diseases)

X-Ray

$\mathrm{IC}_{50}>5 \mathrm{mM}$

$21[48,49]$

DENV-MTase

(Viral diseases)

X-Ray

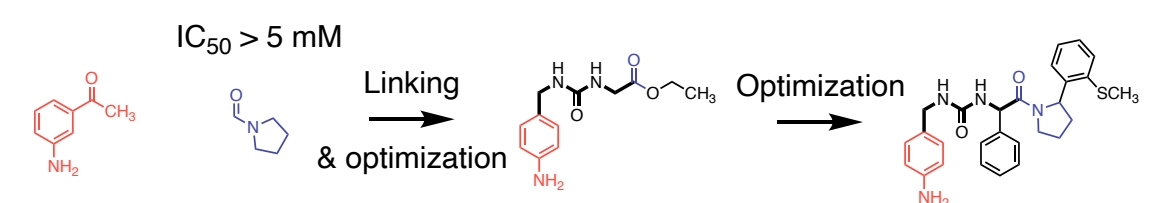

$$
\mathrm{IC}_{50}>5 \mathrm{mM}
$$

$$
\begin{aligned}
& I_{I_{50}}(\text { CYPA })=13.1 \mu \mathrm{M} \\
& I_{50}(\text { CYPB })=6.1 \mu \mathrm{M} \\
& I_{50}(\text { CYPD })=6.2 \mu \mathrm{M}
\end{aligned}
$$

$\mathrm{IC}_{50}$ (CYPA) $=100 \mathrm{nM}$

$\mathrm{IC}_{50}$ (CYPB) $=80 \mathrm{nM}$

$\mathrm{IC}_{50}(\mathrm{CYPD})=200 \mathrm{nM}$
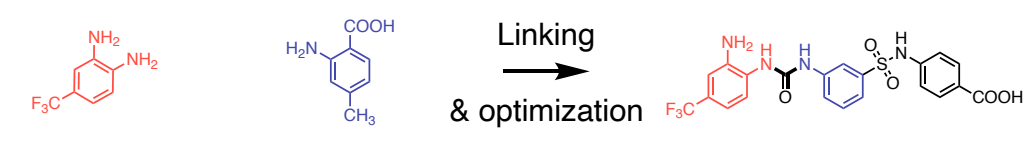

$$
I C_{50}=9 \mathrm{mM} \quad I C_{50}=2.8 \mathrm{mM}
$$

$$
\begin{aligned}
& \mathrm{IC}_{50} \text { (DENV 2'O-MTase) }=91 \mu \mathrm{M} \\
& \mathrm{IC}_{50}(\mathrm{DENV} \text { N7-MTase) }=1.1 \mathrm{mM} \\
& \mathrm{IC}_{50}(\text { WNV 2'O-MTase })=51 \mu \mathrm{M}
\end{aligned}
$$

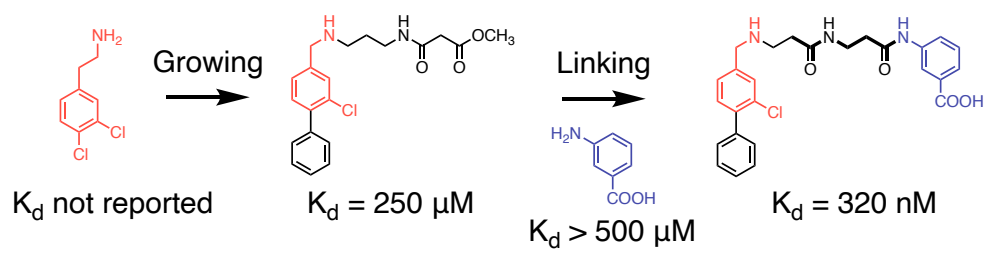


23 [53]

RPA

(Cancer)

NMR

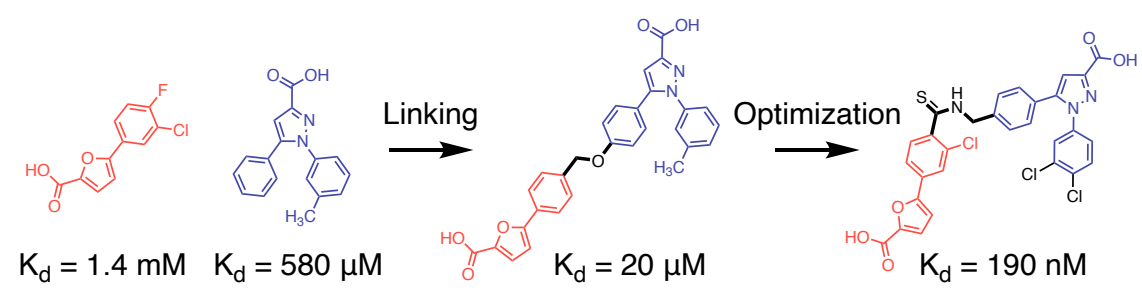

24 [54]

23S rRNA

(Viral \&

bacterial

diseases)

MS

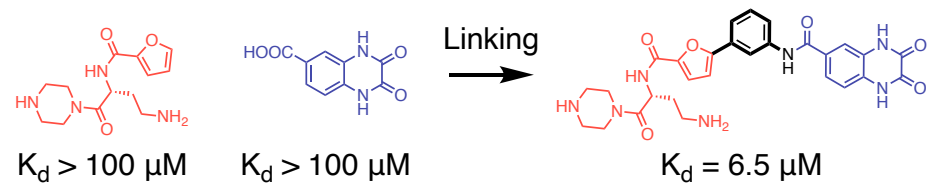

25 [55]

Avidin

-

Bioassay
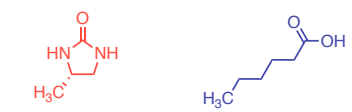

$\stackrel{\text { Linking }}{\longrightarrow}$

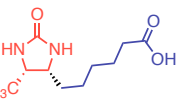

$K_{i}=34 \mu \mathrm{M} \quad K_{i}=260 \mu M$

$\mathrm{K}_{\mathrm{i}}=410 \mathrm{fM}$

$\mathbf{2 6}$ [56]
c-SRC
(Cancer)
Bioassay
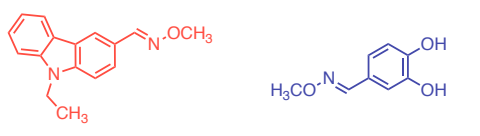

Linking

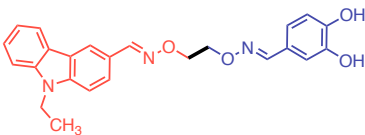

$$
\mathrm{IC}_{50}=40 \mu \mathrm{M} \quad \mathrm{IC}_{50}=41 \mu \mathrm{M}
$$

$\mathrm{IC}_{50}=64 \mathrm{nM}$

27 [57]

CA

(Osteoporosis)

DCC
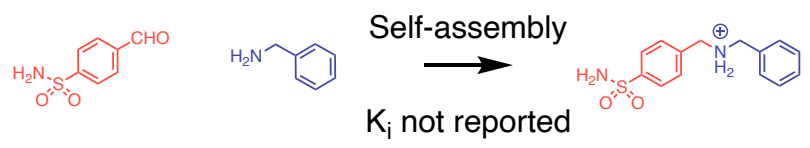

$28[58,59]$

NA

(Viral diseases)

DCC

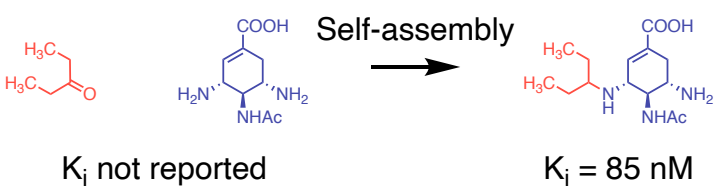

29 [60]

Endothia-

pepsin

(Infectious, viral

\& neuro-

$K_{i}$ not reported

$\mathrm{K}_{\mathrm{i}}=85 \mathrm{nM}$

degenerative

diseases)

DCC 


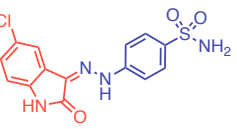

DCX

$$
\mathrm{IC}_{50}>1 \mathrm{mM} \quad \mathrm{IC}_{50}>1 \mathrm{mM}
$$

$\mathrm{IC}_{50}=30 \mathrm{nM}$

31 [62]

\section{CASP3}

(Neurodegenerative diseases) DLS

32 [63]

FXa (Bleeding disorders) DLS

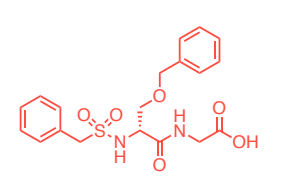
$\mathrm{K}_{\mathrm{i}}=5.5 \mathrm{mM}$

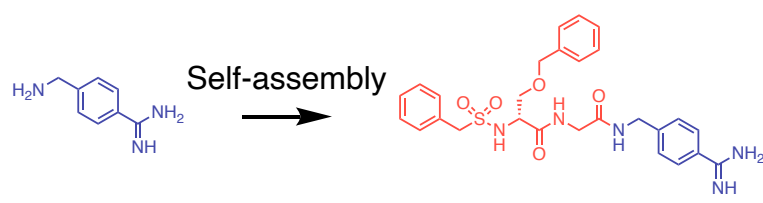

33 [64]

ACHE

(Neurodegenerative diseases)

PTCC

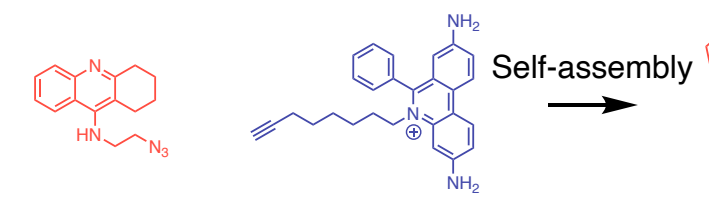

$K_{d}=10-100 n M \quad K_{d}=10-100 m M$

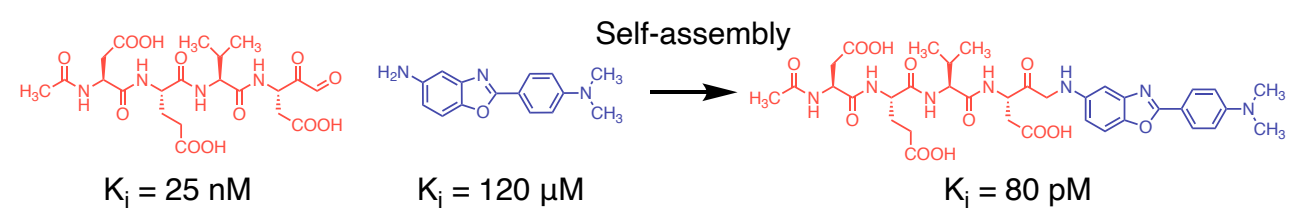

$K_{i}=29 n M$

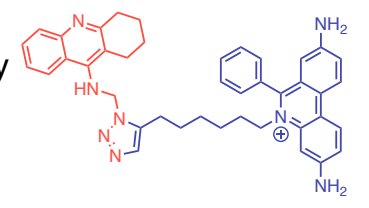

$\mathrm{K}_{\mathrm{d}}=77 \mathrm{fM}$

34 [65]

HDAC

(Cancer, inflammatory \& neurodegenerative diseases) PTCC

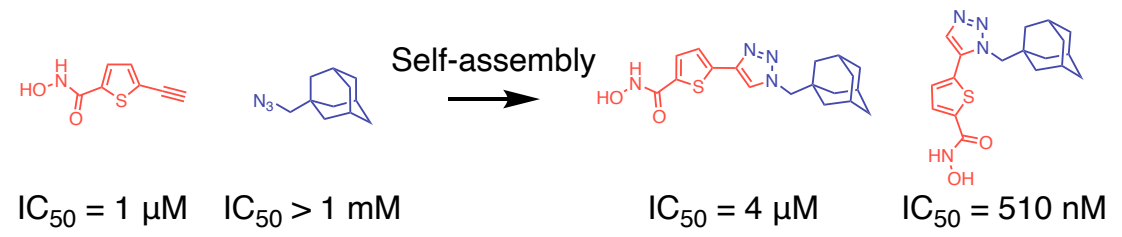

35 [66]

SmChiB

(Infectious \&

inflammatory diseases)

PTCC
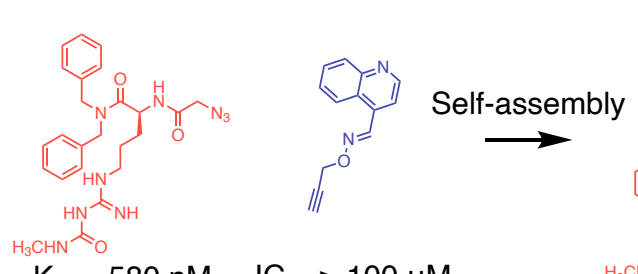

36 [67]

Endothia-

pepsin

(Infectious, viral

\& neuro-

degenerative

diseases)

PTCC 
$37[68,69]$

BCL-X

(Cancer \& autoimmune diseases)

PTCC

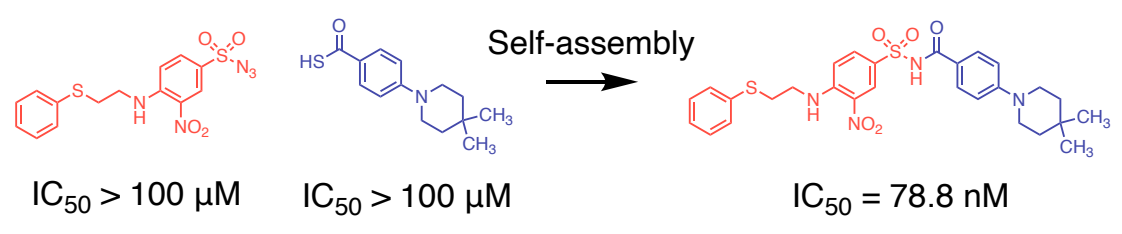

38 [71]

NMT1

(Viral diseases)

X-Ray
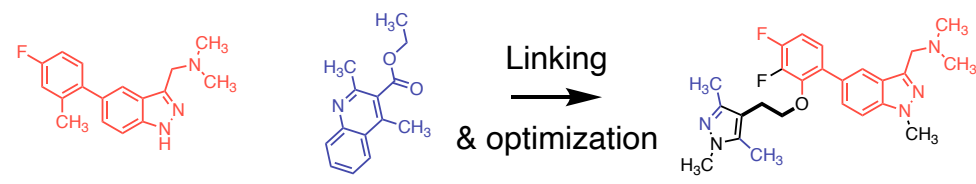

$I_{50}=20 \mu \mathrm{M} \quad I_{50}>100 \mu \mathrm{M}$

$\mathrm{IC}_{50}<1 \mathrm{nM}$

39 [72]

Chymase

(Cardiovascular diseases)

X-Ray

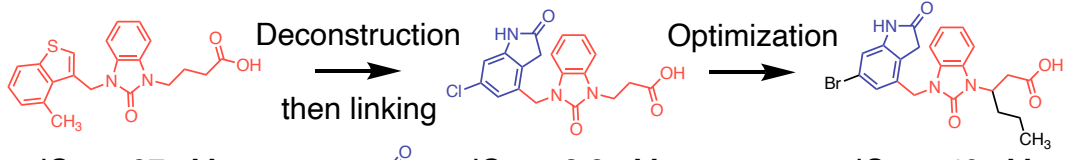

$\mathrm{IC}_{50}=97 \mathrm{nM}$

$\mathrm{IC}_{50}=40 \mathrm{nM}$

$\mathrm{IC}_{50}=470 \mu \mathrm{M}$ 
A

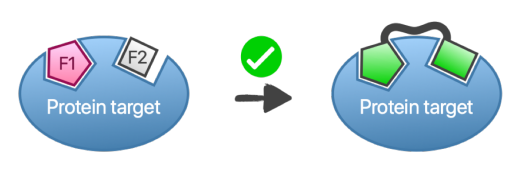

E

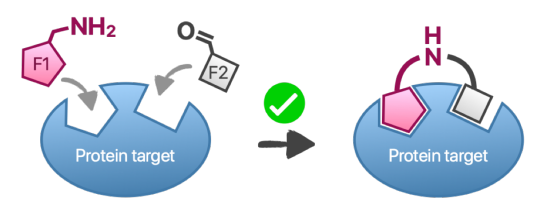

B

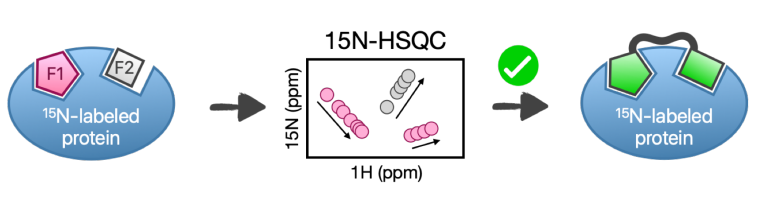

C
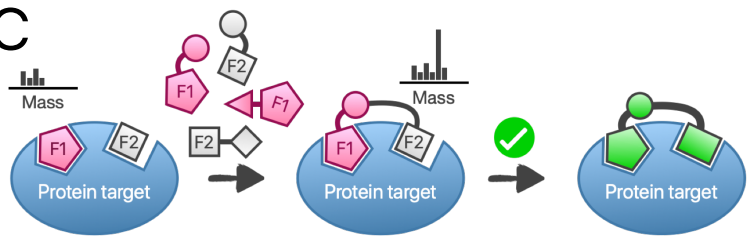

D

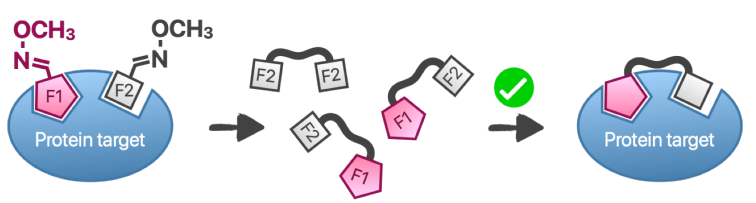

G

F
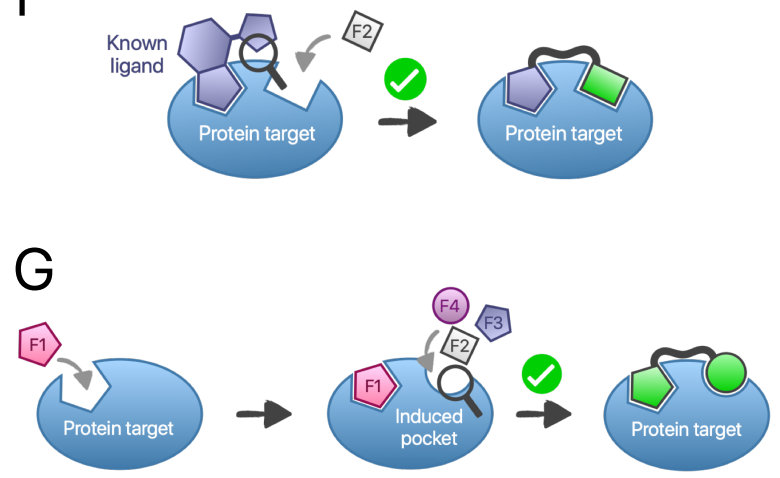

Figure 3. Schematic representation of methods for direct identification of fragment bounds to two

distinct binding sites. A) Screening using X-ray crystallography. When fragments are screened in cocktails, fragments bound to distinct sites can be observed. B) Screening using protein-observed NMR. Two fragments that bind simultaneously two distinct protein pockets can be identified on 2D NMR protein spectra. C) Screening using MS. Fragment hits identified by MS are modified and competition experiments are performed to derive structural restraints. D) Screening using biochemical assays. The example shows the use of the oxime function together with a small library of di-hydroxylamine linkers. E) Fragment self-assembly in the presence of a target protein: dynamic combinatorial chemistry (DCC). The example is illustrated with aldehyde and amine moieties that in situ form imines. F) Inhibitor deconstruction and reconstruction. A known ligand can be improved by replacing a moiety by a fragment hit identified in the presence of the deconstructed fragment. G) Cooperative binding. A first ligand induces a new pocket for a second fragment hit. 


\section{DIMERIZATION OF A FRAGMENT HIT}

A special application of fragment linking is dimerization. This approach allows one to link together two copies of the same fragment binding to either adjacent sites or in the same pocket of a protein.

4.1. The fragment binds twice in the protein binding pocket. The first example was reported by Brimijoin and co-workers ${ }^{74}$ for the acetylcholine esterase. The observation that two copies of an acridine analogue could be modelled in the active site led to the design of dimeric compounds with different linker lengths. An inhibitor that was 1,000-fold more potent than the original molecule was synthesized (Table 4, entry 40). Another case was reported by Blundell and co-workers ${ }^{75}$ for the transcription factor from Mycobacterium tuberculosis (EthR), involved in antibiotic resistance. Thermal shift assay followed by crystallography identified two copies of a fragment hit in the allosteric pocket of the protein, starting from 1,250 fragments (Table 4, entry 41). Similarly, biochemical assay (enzyme inhibition by monitoring NADH absorbance) followed by crystallography identified two copies of a fragment hit in the active site of the protein inosine-5'-monophosphate dehydrogenase (IMPDH) (Table 4, entry 42). ${ }^{76}$ They synthesized an inhibitor that was 2,500-fold more potent than the original molecule.

4.2. The fragment binds in the same pocket in two protein sub-units. Human mast cell tryptase, a trypsin-like serine protease, exists as a tetramer. The ligand benzamidine was modified to contain two benzamidine moieties with a flexible linker region spanning the space between two monomers (Table 4 , entry 43$).{ }^{77}$ With a similar approach, an anti-cancer pyruvate kinase M2 (PKM2) activator was designed (Table 4 , entry 44$)^{78}$ as well as an inhibitor of the $\alpha$-amino-3-hydroxy-5-methyl-4isoxazolepropionic acid (AMPA) receptors (Table 4, entry 45). ${ }^{79}$ 
Table 4. Fragment linking by fragment dimerization

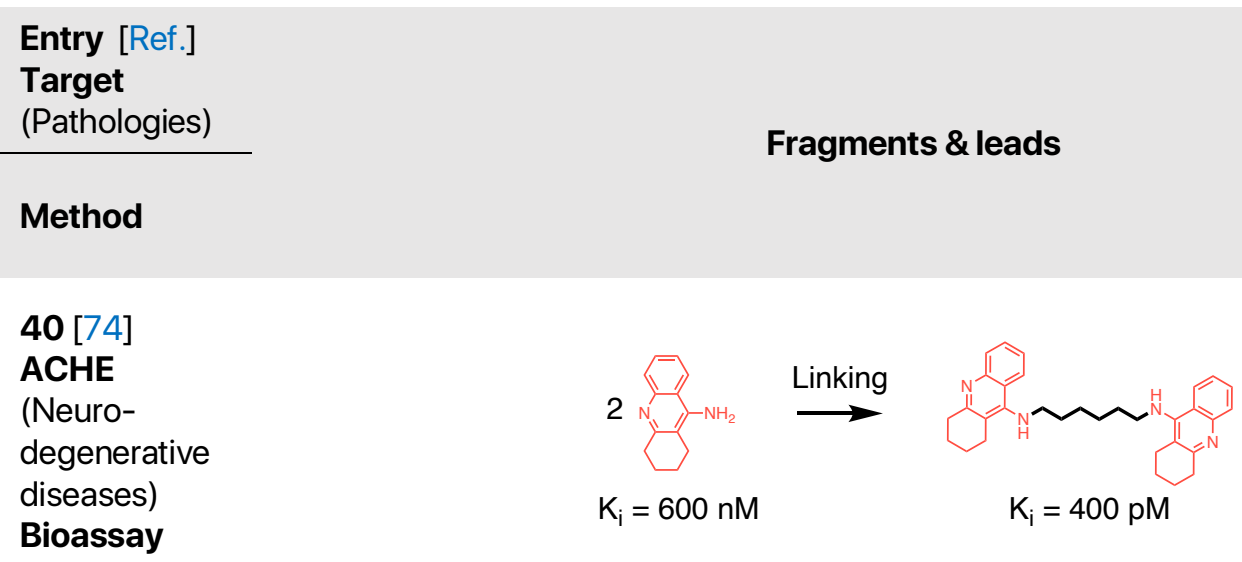

$41[75]$

EthR

(Infectious

diseases)

Bioassay \&

X-Ray

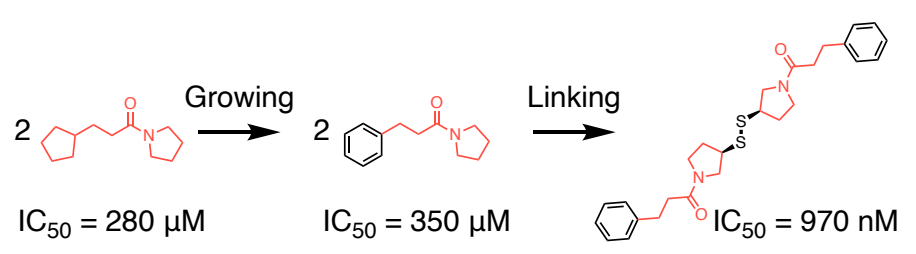

$42[76]$

IMPDH

(Infectious

diseases)

Bioassay \&

X-Ray

IC.

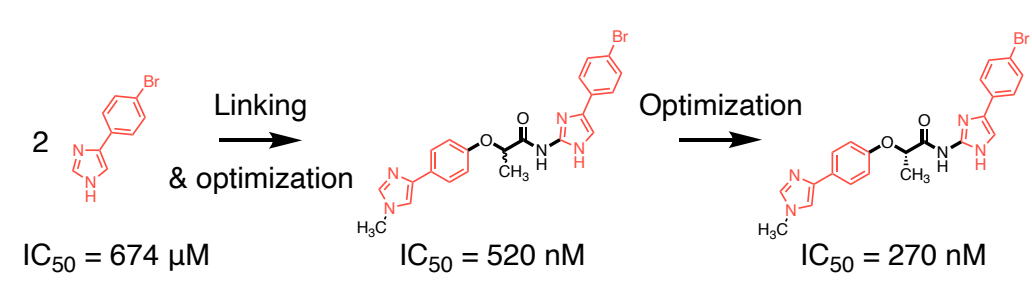

43 [77]

Tryptase

(Asthma)

Bioassay

44 [78]

PKM2

(Cancer)

HTS

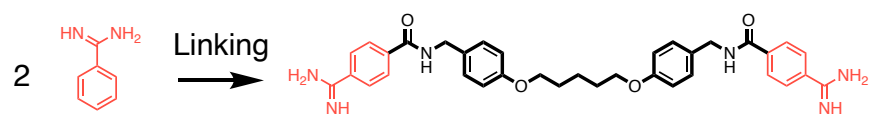

$\mathrm{K}_{\mathrm{i}}=22 \mu \mathrm{M} \quad \mathrm{K}_{\mathrm{i}}<10 \mathrm{pM}$

$45[79]$

AMPA

receptor

(Neuro-

degenerative

diseases)

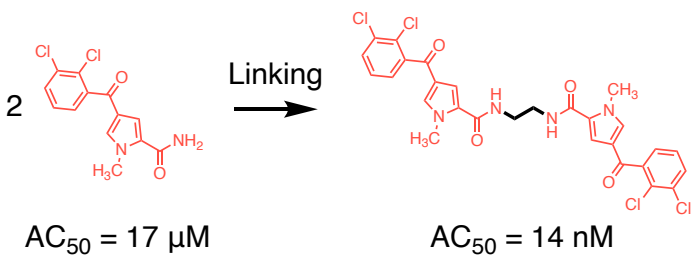

$\mathrm{AC}_{50}=17 \mu \mathrm{M}$

$\mathrm{AC}_{50}=14 \mathrm{nM}$

X-Ray

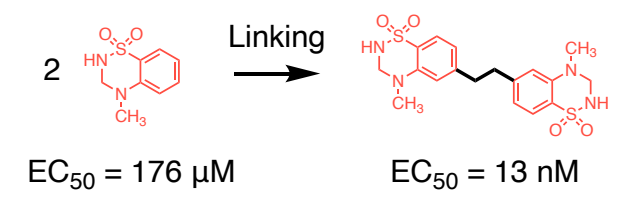




\section{LINKERS}

Once two fragments have been identified, a linker is designed, which can be done using various strategies. From a chemical point of view, we have considered two types of linkers, the alkyl-derived linkers, and the functionalized linkers. We also report two promising approaches, a first one that we have called "linkers inspired by known ligands" and the other one "growing before linking".

5.1. Alkyl linkers and derivatives. Alkyl linkers of variable lengths are largely used in the literature to link two fragments bound in two pockets (Table 5). In some studies, the linkers also include more rigid structures such as phenyl core, alkyne function (Table 5 entry 11) and cyclohexane (Table 5 entry 26). Typically, the likely binding mode and structural constraints for the lengths are obtained from NMR experiments (Table 5 entries $1,2 \& 3$ ), crystal structure of fragments (Table 5 entries $4,6,18,38 \& 39$ ) or a combination of crystallography and molecular modelling (Table 5 entries $7,12,16,17,19,40,44$ \& 45). One publication showed that mass spectroscopy competition experiments can also generate distance restraints (Table 5 entry 24). Linking strategy with an alkyl chain has also successfully generated compounds in the absence of structural information, using biochemical data (Table 5 entries $25 \& 43)$.

In a majority of cases, a small set of compounds with varying linker lengths and attachment points are synthesized to explore the hypotheses. In addition, the linking can start from an ether or an amine moiety, making chemical synthesis more straightforward.

5.2. Linkers with functional groups. Alkyl functions are more problematic when the linking of the two molecules requires a non-linear geometry. For example, the team of Barral used a urea function as suggested by in silico studies (Table 5 entry 21). Hadjuk and co-workers reported a case where a sulfonamide was chosen as it could bend by $180^{\circ}$. In the same study, in order to position correctly a furanone moiety included in the fragment with a $90^{\circ}$ twist, an acetylene linker was used (Table 5 entry 5). Sulfonamide and acyl sulfonamide were also used by the Abell group to replace ester and amide moieties in the case of the pantothenate synthase (Table 5 entry 9). 
5.3. Structural data for the linker design. As illustrated in Table 5, in the large majority of the cases (26 out of 31 publications), structural information is used to design the linker. X-ray crystallography appears as the method of choice, alone or in combination with modeling, while NMR is much rarely utilized. Structural data can also result from the merging strategy, where a known ligand offers an opportunity to design the linker (see below, 5.4). Also, the growing strategy may be necessary to first reduce the distance between the fragments before linking, which necessitates structural characterization of the protein-fragment complexes (see 5.5).

\subsection{Linkers inspired by known ligands (mixing merging and linking strategies). Another strategy} for the linker design is to take advantage of the knowledge of natural substrates or other known inhibitors. For example, Guichou et al. chose to use a urea moiety, after superimposition of fragments with the known structures of sangliferin $\mathrm{A}$ and cyclosporine A, two cyclophilin inhibitors. Two molecules with two different linkers were obtained and one of them directly showed micromolar activity (Table 5 entry 20). Abell group similarly merged a previously known inhibitor with two copies of a fragment hit (Table 5 entry 42), which has led to a successful linker.

5.5. Growing before linking. We want to particularly emphasize one strategy that consists in growing one of the fragments before linking, when the distance between the two fragments is particularly large. 
This strategy has been used with both alkyl and functionalized linkers. In the report by AstraZeneca (Table 5 entry 16) on the LDHA protein, growing of one of the fragments was performed until the distance between the two fragments was reduced to $3 \AA$. Then, a molecular study was used to select suitable linkers. In the case of the protein kinase CK2, due to the long distance between the initial fragments, Spring and colleagues choose to modify one of the fragments by addition of chemical groups with different lengths. The synthesized molecules were then evaluated and X-ray data were solved to measure the resulting distance between the two fragments (Table 5 entry 22), before linking. 
Table 5. Linker chemical structures and structural methods.

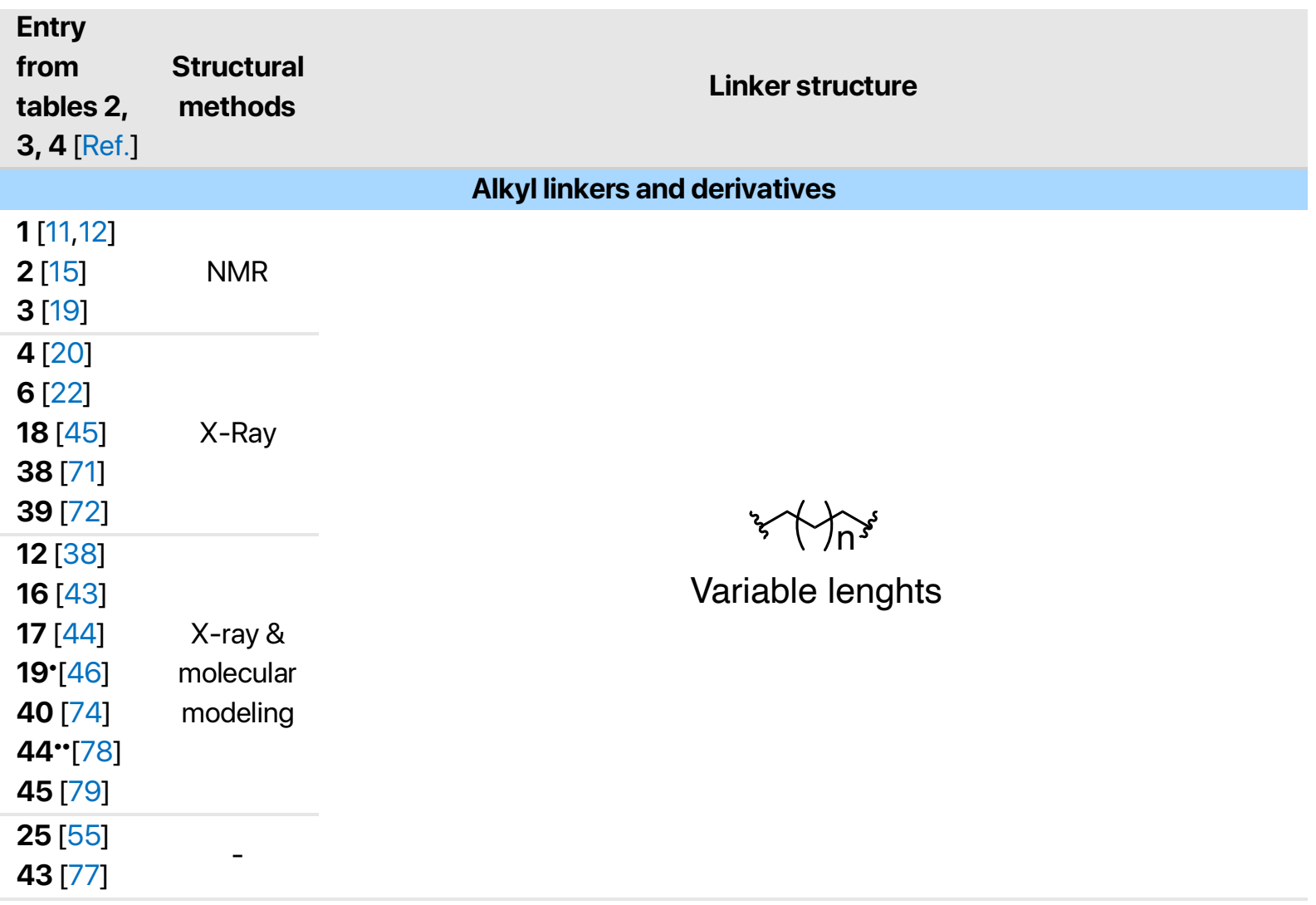

7 [23] $\quad \begin{gathered}\text { X-ray \& } \\ \text { molecular } \\ \text { modeling }\end{gathered}$<smiles>CCC=CCOCC=C(C)C</smiles>

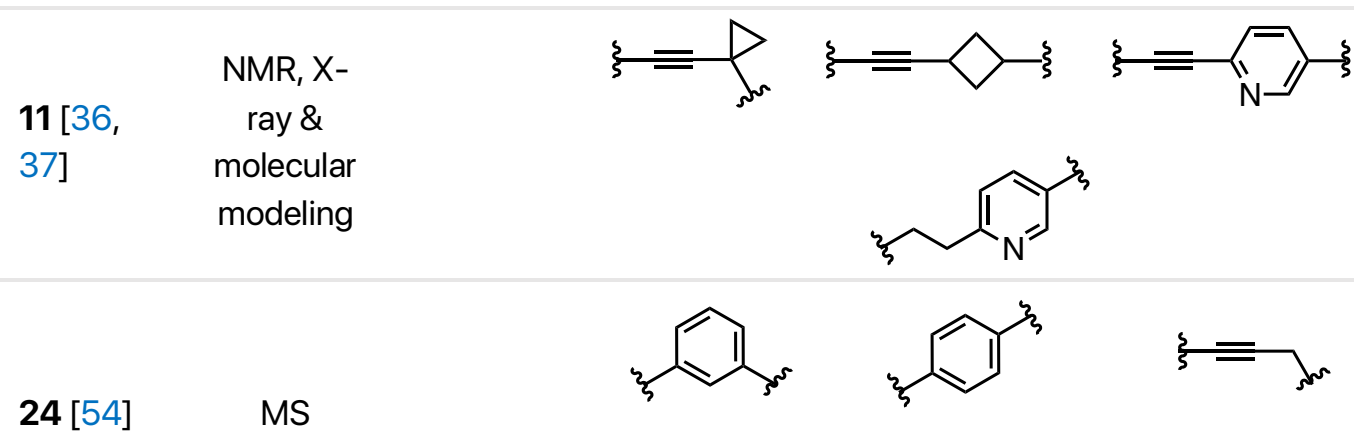

$26[56]$
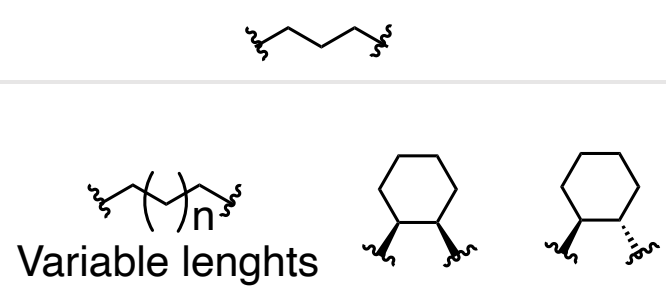


\section{Linkers with functional groups}

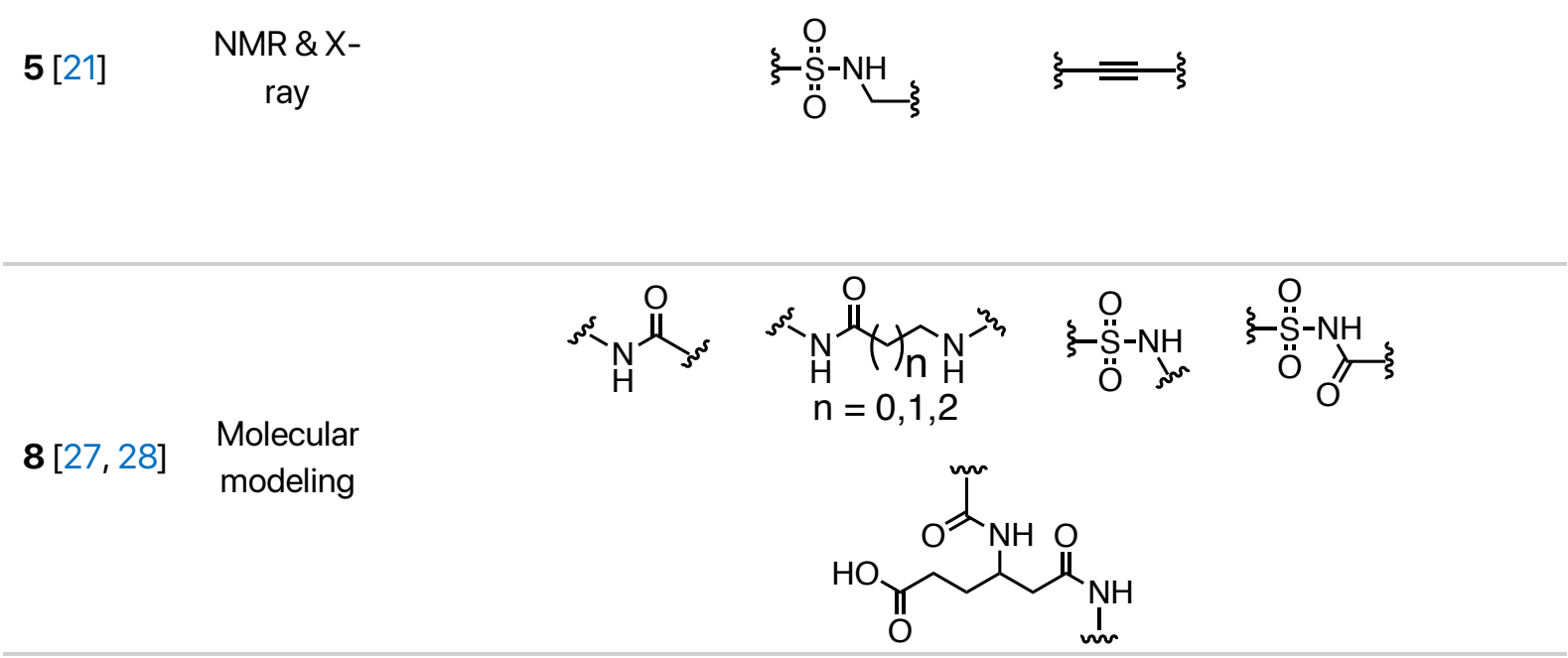

13 [39]<smiles>CCOCCCOCCCOC(C)C</smiles><smiles>CCOCCCNC(=O)COC</smiles><smiles>COCC(O)C(O)C(O)C(O)COC</smiles><smiles>CNCC(O)[C@@H](O)C(O)COC</smiles><smiles>COCC(O)C(O)C(O)COC</smiles>

20 [47]<smiles>CCCNC(=O)NCCC</smiles>

X-ray

23 [53]

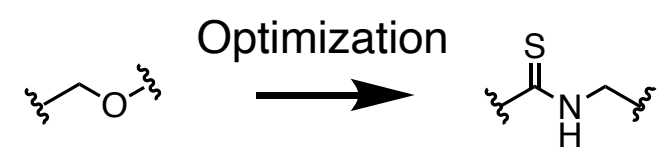

$42[76]$

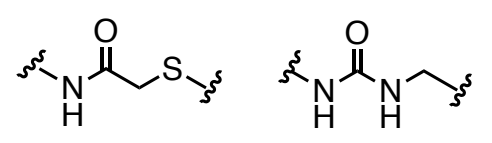<smiles>CC(C)NC(=O)[C@@H](C)OC(C)C</smiles> 


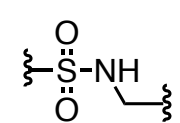<smiles>COC1NOCO1</smiles>

21[48,

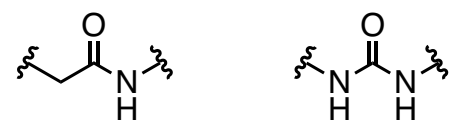

X-ray \& molecular modeling

22 [50-

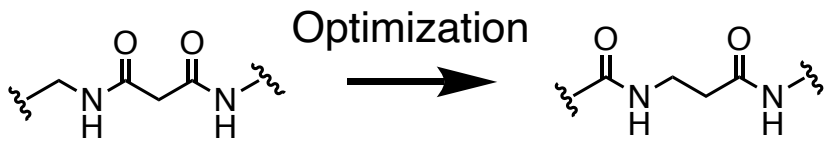

$41[75]$<smiles>CCC(=O)N[14CH2]</smiles><smiles>CCSSCC</smiles>

- Ranking by calculating the internal-strain energies

* Molecular dynamics simulation

\section{FUTURE PERSPECTIVES AND CONCLUSION}

FBDD is a powerful method for the generation of new drug candidates, which so far has led to three FDA-approved drugs and to clinical trials for nearly fifty molecules. While strategies for developing an active molecule from a fragment are typically growing, linking and merging approaches, some examples reported here show that these strategies may be used one after another to increase the chances of success. 
Nevertheless, the literature clearly shows that the growing strategy is by far the most widely used strategy, even if the linking strategy raised great expectations due to theoretical considerations. ${ }^{14}$ Are there some experimental, technical difficulties that might explain the moderate success of the linking strategy? The first step in this process is the identification of two fragments that bind the protein in two distinct sub-sites. Screening a fragment library with a structural method offers a clear advantage in this context. While both NMR and X-Ray crystallography techniques theoretically offer the opportunity to directly identify two compounds that simultaneously bind the protein target at two different sites, published examples highlight X-Ray crystallography as the most successful (or used) method. By contrast, NMR is a method of choice for the iterative identification of a second-site binder.$^{80}$ However, when using NMR as a screening technique, two screens are generally essential. Second-site screening also offers the opportunity to identify new binding pockets, which may open the route for the design of highly selective compound such as allosteric molecules. The optimization of the second-site ligands might be necessary to increase the affinity of those ligands that are typically weaker binders than the first-site ligands. Once the screening has been performed, the most appropriate method to guide the linking process will depend on the distance between the two identified binders. NMR can be an interesting approach for short distances, typically when the two fragments bind in adjacent pockets, using ILOE 2D experiments that do not require protein labeling. We believe this strategy is particularly suitable for catalytic sites of enzymes (Table 2, entries $8 \& 9$ ). For larger distances, which might be observed for protein-protein interaction inhibitors or for bivalent compounds targeting two sites (for example active site and allosteric site), modelisation and X-Ray crystallography are more efficient techniques than NMR, as the linker design will necessitate the resolution of the complex 3D structure. NMR would require labeled protein samples.

For the majority of the fragment-linking published examples, super-additivity is not observed. This might explain why the growing approach remains the preferred strategy. Out of the forty-five examples reported here, nine only fulfill the super-additivity criterium (Entries $2,4,18,20,25,30,32,33 \& 43$ ), including the well-known avidin case, one dimerization case and three self-assembly examples. This shows that achieving super-additivity is challenging. In particular for non-catalytic sites such as proteinprotein interaction sites, protein conformational rearrangement upon compound binding might induce 
changes in the fragment binding modes. Translational and rotational entropy changes due to the linker also need to be counteracted. It is not straightforward to understand what criteria (regarding the fragment or the linker) lead to super-additivity. Previously, Whittaker and colleagues ${ }^{13}$ suggested that successful linking could be achieved by carefully selecting the pair of fragments to be linked, with one forming polar interactions with the protein while the second fragment should interact through van der Waals interactions. The idea is that the binding mode of the fragment that does bind through nonpolar interactions can be changed without penalty upon linking. There are examples in the literature that contradict this assumption and successful cases here showed polar interactions for both fragments. To our point of view, the linking strategy in FBDD essentially depends on the optimization of the two initial fragments, the geometry required to link the fragments and the length of the linker. As observed for the compounds for which the super-additivity was reached, the linkers are rather short and flexible, mainly alkyl-derived linkers. Therefore, these findings tend to suggest that mixing the growing and linking approaches could be a promising method to achieve the super-additivity. Growing one fragment helps reduce the length of the linker required. Also, optimization of the fragments before linking may help adapt the linker in case of protein conformational changes. Another promising approach consists in mixing merging and linking strategies, where the linker is designed thanks to the imitation of chemical groups observed in known ligands.

\section{AUTHOR INFORMATION}

\section{Corresponding Author}

*E-mail: isabelle.krimm@univ-lyon1.fr. Phone: +33437423544

\section{ORCID}

Alexandre Bancet : 0000-0003-4467-8684

Claire Raingeval: 0000-0002-1161-429X

Thierry Lomberget: 0000-0002-4071-0002

Marc Le Borgne: 0000-0003-1398-075X

Jean-François Guichou: 0000-0002-7699-3235

Isabelle Krimm: 0000-0002-5981-109X 


\begin{abstract}
Notes
The authors declare no competing financial interest.
\end{abstract}

\title{
Biographies
}

Alexandre Bancet received his Master's degree in Chemistry in 2017 from the University of Lyon, France. He is currently pursuing his Doctoral degree in Medicinal Chemistry under the supervision of Prof. Thierry Lomberget and Dr. Isabelle Krimm. He is developing a non ATP-competitive inhibitor of the CK2 kinase using fragment-based approaches and the NMR technique, at the Institut of Pharmacological Sciences, University of Lyon, and at The Very High field NMR Center in Lyon.

Claire Raingeval received her Ph.D. from the Chemistry Department at the University of Lyon, France, in 2019, under the supervision of Dr Isabelle Krimm at the The Very High field NMR Center in Lyon. Her research was focused on fragment screening against the $G$ protein-coupled receptors.

Thierry Lomberget obtained his Ph.D. in Organometallic Chemistry from University of Lyon in 2002 under the supervision of Dr. Geneviève Balme. After a two years' post-doctoral stay at the University of Geneva in the research group of Prof. E. Peter Kündig, he came back to Lyon as a temporary teacher/researcher and then was appointed as a lecturer at ISPB - Faculty of Pharmacy of Lyon in 2005. He was promoted as a full professor of medicinal chemistry in 2016 at the same institute. His actual main research interests are the design and optimization of anticancer agents, such as microtubuletargeting agents and kinases inhibitors, multidrug resistance modulators and anti-infective compounds.

Marc Le Borgne has his Ph.D. in medicinal chemistry under the supervision of Prof. Guillaume Le Baut at the University of Nantes (France) in 1997. He began his research and academic career in the School of Pharmacy at the University of Nantes. In 2008, he moved to the University of Lyon as a full professor in medicinal chemistry. He is currently the Head of the research Team Bioactive Molecules and Medicinal Chemistry (B2MC). His research interests focus on the design and synthesis of bioactive small molecules as anti-infective compounds or kinase-targeted anticancer therapeutic agents. 


\section{ACKNOWLEDGMENTS}

We thank the CNRS, the Ligue contre le cancer and ANR (Convergence PLAScan) for financial support.

\section{ABBREVIATIONS USED}

AMPA, $\alpha$-amino-3-hydroxy-5-methyl-4-isoxazolepropionic acid; ACHE, acetylcholinesterase; AdoMet, adenosylmethionine; AKT, protein kinase B; ATP, adenosine triphosphate; BACE1, betasecretase 1; BCL-2, B-cell lymphoma 2; BCL-X $\mathrm{X}_{\mathrm{L}}$, B-cell lymphoma-extra-large; BET, bromo- and extra-terminal domain family; BRAF, v-raf murine sarcoma viral oncogene homolog B; BRD2, bromodomain-containing protein 2; c-SRC, proto-oncogene tyrosine-protein kinase SRC; CA, carbonic anhydrase; CASP3, caspase 3; CDK1/2/4/5/9, cyclin-dependent kinases 1/2/4/5/9; cIAP1, cellular inhibitor of apoptosis protein 1; CK2, casein kinase 2; CSF1R, colony stimulating factor 1 receptor; CYPD, cyclophilin D; DCC, dynamic combinatorial chemistry; DENV, dengue virus; DLS, dynamic 
ligation screening; DOT1L, disruptor of telomeric silencing 1-like; ERK1/2, mitogen-activated protein kinase 3/1; EthR, mycobacterium tuberculosis transcriptional repressor; FAXS, fluorine chemical shift anisotropy and exchange for screening; FBDD, Fragment-based drug discovery; FDA, Food and Drug Administration; FGFR, fibroblast growth factor receptors; FKBP, FK506-binding protein; FLT3, fmslike tyrosine kinase 3; FXa, factor X; HDAC, histone deacetylases; HIV-1, human immunodeficiency virus 1; HSP90, heat shock protein 90; HTS, high-throughput screening; IDO1, indoleamine-pyrrole 2,3-dioxygenase; IL-2, interleukin 2; ILOEs, inter-ligand NOEs; IMPDH, inosine-5'-monophosphate dehydrogenase; IRAK4, interleukin-1 receptor-associated kinase 4; JAK2, Janus kinase 2; KHK, ketohexokinase; KIT, tyrosine-protein kinase KIT; KRAS, kirsten rat sarcoma viral oncogene; LDHA, lactate deshydrogenase A; LFA1, lymphocyte function-associated antigen 1; LTA4H, leukotriene A4 hydrolase; MCL1, induced myeloid leukemia cell differentiation protein; MET, tyrosine-protein kinase MET; mGlu5, metabotropic glutamate receptor 5; MNK1/2, MAP kinase-interacting serine/threonineprotein kinase 1/2; MMP2/9, matrix metalloproteinase 2/9; mRNA, messenger ribonucleic acid; MS, Mass Spectrometry; MTase, methyltransferase; NA, neuraminidase; NADH, nicotinamide adenine dinucleotide; NMR, Nuclear Magnetic Resonance; NMT1, $N$-myristoyltransferase 1; NOE, nuclear overhauser effect; NOESY, nuclear overhauser effect spectroscopy; PKM2, pyruvate kinase M2; PPAR, peroxisome proliferator-activated receptor; PRC2, polycomb repressive complex 2; PRE, paramagnetic enhancement; PS, pantothenate synthetase; PTCC, protein-templated click chemistry; PTP1B, protein tyrosine phosphatase-1B; RAF, rapidly accelerated fibrosarcoma; ROCK, rho-associated protein kinase; RPA, replication protein A; rRNA, ribosomal ribonucleic acid; S6K1, ribosomal protein S6 kinase beta1; SAM, S-adenosylmethionine; SAR, structure-activity relationships; SmChiB, serratia marcescens chitinase B; SPR, surface plasmon resonance; STD, Saturation Transfer Difference; TEMPO, 2,2,6,6tetramethylpiperidin-1-oxyl; VRE, vancomycin-resistant enterococci; XIAP, x-linked inhibitor of apoptosis protein 


\section{REFERENCES}

(1) Rees, D. C.; Congreve, M.; Murray, C. W.; Carr, C. Fragment-based lead discovery. Nature. 2004, 3, 660-672.

(2) Hajduk, P. J.; Greer, J. A decade of fragment-based drug design: strategic advances and lessons learned. Nat. Rev. Drug Discov. 2007, 6, 211-219.

(3) Chessari, G.; Woodhead, A. J. From fragment to clinical candidate - a historical perspective. Drug Discov. Today. 2009, 14, 668-675.

(4) Murray, C. W.; Blundell, T. L. Structural biology in fragment-based drug design. Curr. Opin. Struct. Biol. 2010, 20 , 497-507.

(5) Erlanson, D. A.; Fesik, S. W.; Hubbard, R. E.; Jahnke, W.; Jhoti, H. Twenty years on: the impact of fragments on drug discovery. Nat. Rev. Drug Discov. 2016, 15, 605-619.

(6) Mortenson, P. N.; Erlanson, D. A.; de Esch, I. J. P.; Jahnke, W.; and Johnson, C. N. Fragment-to-lead medicinal chemistry publications in 2017. J. Med. Chem. 2019, 62, 3857-3872.

(7) Congreve, M.; Carr, R.; Murray, C.; Jhoti, H. A "Rule of three" for fragment-based lead discovery. Drug Discov. Today. 2003, 8, 876-877.

(8) Bollag, G.; Hirth, P.; Tsai, J.; Zhang, J.; Ibrahim, P. N.; Cho, H.; Spevak, W.; Zhang, C.; Zhang, Y.; Habets, G.; Burton, E. A.; Wong, B.; Tsang, G.; West, B. L.; Powell, B.; Shellooe, R.; Marimuthu, A.; Nguyen, H.; Zhang, K. Y.; Artis, D. R.; Schlessinger, J.; Su, F.; Higgins, B.; Iyer, R.; D'Andrea, K.; Koehler, A.; Stumm, M.; Lin, P. S.; Lee, R. J.; Grippo, J.; Puzanov, I.; Kim, K. B.; Ribas, A.; McArthur, G. A.; Sosman, J. A.; Chapman, P. B.; Flaherty, K. T.; Xu, X.; Nathanson, K. L.; Nolop, K. Clinical efficacy of a RAF inhibitor needs broad target blockade in BRAFmutant melanoma. Nature. 2010, 467, 596-599.

(9) Souers, A. J; Leverson, J. D.; Boghaert, E. R.; Ackler, S. L.; Catron, N. D.; Chen, J.; Dayton, B. D.; Ding, H.; Enschede, S. H.; Fairbrother, W. J.; Huang, D. C. S.; Hymowitz, S. G.; Jin, S.; Khaw, S. L.; Kovar, P. J.; Lam, L. T.; Lee, J.; Maecker, H. L.; Marsh, K. C.; Mason, K. D.; Mitten, M. J.; Nimmer, P. M.; Oleksijew, A.; Park, C. H.; Park, C.; Phillips, D. C.; Roberts, A. W.; Sampath, D.; Seymour, J. F.; Smith, M. L.; Sullivan, G. M.; Tahir, S. K.; Tse, C.; Wendt, M. D.; Xiao, Y.; Xue, J. C.; Zhang, H.; Humerickhouse, R. A.; Rosenberg, S. H.; Elmore, S. W. ABT-199, a potent and selective BCL-2 inhibitor, achieves antitumor activity while sparing platelets. Nat. Med. 2013, 19, 202208.

(10) Murray, C. W.; Newell, D. R.; Angibaud, P. A successful collaboration between academia, biotech and pharma led to discovery of erdafitinib, a selective FGFR inhibitor recently approved by the FDA. MedChemComm. 2019, 10, 1509-1511.

(11) Shuker, S. B.; Hajduk, P. J.; Meadows, R. P.; Fesik, S. W. Discovering high-affinity ligands for proteins : SAR by NMR. Science. 1996, 274, 1531-1534.

(12) Hajduk, P. J.; Meadows, R. P.; Fesik, S. W. Discovering high-affinity ligands for proteins. Science. 1997, 278, 497499. 
(13) Ichihara, O.; Barker, J.; Law, R. J.; Whittaker, M. Compound design by fragment-linking. Mol. Inform. 2011, 30, 298-306.

(14) Jencks, W. On the attribution and additivity of binding energies. Proc. Natl. Acad. Sci. U.S.A. 1981, 78 (7), 40464050.

(15) Hajduk, P. J.; Sheppard, G.; Nettesheim, D. G.; Olejniczak, E. T.; Shuker, S. B.; Meadows, R. P.; Steinman, D. H.; Carrera, G. M.; Marcotte, P. A.; Severin, J.; Walter, K.; Smith, H.; Gubbins, E.; Simmer, R.; Holzman, T. F.; Morgan, D. W.; Davidsen, S. K.; Summers, J. B.; Fesik, S. W. Discovery of potent nonpeptide inhibitors of stromelysin using SAR by NMR. J. Am. Chem. Soc. 1997, 119, 5818-5827.

(16) Oltersdorf, T.; Elmore, S. W.; Shoemaker, A. R.; Armstrong, R. C.; Augeri, D. J.; Belli, B. A.; Bruncko, M.; Deckwerth, T. L.; Dinges, J.; Hajduk, P. J.; Joseph, M. K.; Kitada, S.; Korsmeyer, S. J.; Kunzer, A. R.; Letai, A.; Li, C.; Mitten, M. J.; Nettesheim, D. G.; Ng, S.; Nimmer, P. M.; O'Connor, J. M.; Oleksijew, A.; Petros, A. M.; Reed, J. C.; Shen, W.; Tahir, S. K.; Thompson, C. B.; Tomaselli, K. J.; Wang, B.; Wendt, M. D.; Zhang, H.; Fesik, S. W.; Rosenberg, S. H. An inhibitor of BCL-2 family proteins induces regression of solid tumours. Nature. 2005, 435, 677681.

(17) Petros, A. M.; Dinges, J.; Augeri, D. J.; Baumeister, S. A.; Betebenner, D. A.; Bures, M. G.; Elmore, S. W.; Hajduk, P. J.; Joseph, M. K.; Landis, S. K.; Nettesheim, D. G.; Rosenberg, S. H.; Shen, W.; Thomas, S.; Wang, X.; Zanze, I.; Zhang, H.; Fesik, S. W. Discovery of a potent inhibitor of the antiapoptotic protein Bcl- $\mathrm{X}_{\mathrm{L}}$ from NMR and parallel synthesis. J. Med. Chem. 2006, 49, 656-663.

(18) Tse, C.; Shoemaker, A. R.; Adickes, J.; Anderson, M. G.; Chen, J.; Jin, S.; Johnson, E. F.; Marsh, K. C.; Mitten, M. J.; Nimmer, P.; Roberts, L.; Tahir, S. K.; Xiao, Y.; Yang, X.; Zhang, H.; Fesik, S.; Rosenberg, S. H.; Elmore, S. W. ABT-263: A potent and orally bioavailable Bcl-2 family inhibitor. Cancer Res. 2008, 68, 3421-3428.

(19) Petros, A. M.; Huth, J. R.; Oost, T.; Park, C. M.; Ding, H.; Wang, X.; Zhang, H.; Nimmer, P.; Mendoza, R.; Sun, C.; Mack, J.; Walter, K.; Dorwin, S.; Gramling, E.; Ladror, U.; Rosenberg, S. H.; Elmore, S. W.; Fesik, S. W.; Hajduk, P. J. Discovery of a potent and selective Bcl-2 inhibitor using SAR by NMR. Bioorg. Med. Chem. Lett. 2010, 20, $6587-6591$.

(20) Tao, Z. F.; Hasvold, L.; Wang, L.; Wang, X.; Petros, A. M.; Park, C. H.; Boghaert, E. R.; Catron, N. D.; Chen, J.; Colman, P. M.; Czabotar, P. E.; Deshayes, K.; Fairbrother, W. J.; Flygare, J. A.; Hymowitz, S. G.; Jin, S.; Judge, R. A.; Koehler, M. F.; Kovar, P. J.; Lessene, G.; Mitten, M. J.; Ndubaku, C. O.; Nimmer, P.; Purkey, H. E.; Oleksijew A.; Phillips, D. C.; Sleebs, B. E.; Smith, B. J.; Smith, M. L.; Tahir, S. K.; Watson, K. G.; Xiao, Y.; Xue, J.; Zhang, H.; Zobel, K.; Rosenberg, S. H.; Tse, C.; Leverson, J. D.; Elmore, S. W.; Souers, A. J. Discovery of a potent and selective Bcl- $\mathrm{X}_{\mathrm{L}}$ inhibitor with in vivo activity. ACS Med. Chem. Lett. 2014, 5, 1088-1093.

(21) Huth, J. R.; Park, C.; Petros, A. M.; Kunzer, A. R.; Wendt, M. D.; Wang, X.; Lynch, C. L.; Mack, J. C.; Swift, K. M.; Judge, R. A.; Chen, J.; Richardson, P. L.; Jin, S.; Tahir, S. K.; Matayoshi, E. D.; Dorwin, S. A.; Ladror, U. S.; 
Severin, J. M.; Walter, K. A.; Bartley, D. M.; Fesik, S. W.; Elmore, S. W.; Hajduk, P. J. Discovery and Design of Novel HSP90 inhibitors using multiple fragment-based design strategies. Chem. Biol. Drug. Des. 2007, 70, 1-12.

(22) Szczepankiewicz, B. G.; Liu, G.; Hajduk, P. J.; Abad-Zapatero, C.; Pei, Z.; Xin, Z.; Lubben, T. H.; Trevillyan, J. M.; Stashko, M. A.; Ballaron, S. J.; Liang, H.; Huang, F.; Hutchins, C. W.; Fesik, S. W.; Jirousek, M. R. Discovery of a potent, selective protein tyrosine phosphatase 1B inhibitor using a linked-fragment strategy. J. Am. Chem. Soc. 2003, $125,4087-4096$.

(23) Liu, G.; Xin, Z.; Pei, Z.; Hajduk, P. J.; Abad-Zapatero, C.; Hutchins, C. W.; Zhao, H.; Lubben, T. H.; Ballaron, S. J.; Haasch, D. L.; Kaszubska, W.; Rondinone, C. M.; Trevillyan, J. M.; Jirousek, M. R. Fragment screening and assembly: a highly efficient approach to a selective and cell active protein tyrosine phosphatase 1B inhibitor. J. Med. Chem. 2003, 46, 4232-4235.

(24) Krimm, I. INPHARMA-based identification of ligand binding site in fragment-based drug design. MedChemComm. 2012, 3, 605-610.

(25) Li, D.; DeRose, E. F.; London R. E. The inter-ligand Overhauser effect: a powerful new NMR approach for mapping structural relationships of macromolecular ligands. J. Biomol. NMR. 1999, 15, 71-76.

(26) Leone, M.; Freeze, H. H.; Chan, C. S.; Pellechia, M. The Nuclear Overhauser Effect in the lead identification process. Curr. Drug Discov. Technol. 2006, 3, 91-100.

(27) Becattini, B.; Culmsee, C.; Leone, M.; Zhai, D.; Zhang, X.; Crowell, K. J.; Rega, M. F.; Landshamer S.; Reed, J. C.; Plesnila, N.; Pellecchia, M. Structure-activity relationships by interligand NOE-based design and synthesis of antiapoptotic compounds targeting Bid. Proc. Natl. Acad. Sci. U.S.A. 2006, 103, 12602-12606.

(28) Rega, M. F.; Wu, B.; Wei, J.; Zhang, Z.; Cellitti, J. F.; Pellecchia, M. SAR by interligand nuclear overhauser effects (ILOEs) based discovery of acylsulfonamide compounds active against Bcl-X $\mathrm{X}_{\mathrm{L}}$ and Mcl-1. J. Med. Chem. 2011, 54, 6000-6013.

(29) Sledz, P.; Silvestre H. L.; Hung, A. W.; Ciulli, A.; Blundell, T. L.; Abell, C. Optimization of the interligand Overhauser effect for fragment linking: application to inhibitor discovery against Mycobacterium tuberculosis pantothenate synthetase. J. Am. Chem. Soc. 2010, 132, 4544-4545.

(30) Hung, A. W.; Sivestre, H. L.; Wens, S.; Ciulli, A.; Blundell, T. L.; Abell, C. Application of fragment growing and fragment linking to the discovery of inhibitors of Mycobacterium tuberculosis pantothenate synthetase. Angew. Chem. Int. Ed. Engl. 2009, 48, 8452-8456.

(31) Jahnke, W. Spin labels as a tool to identify and characterize protein-ligand interactions by NMR spectroscopy. ChemBioChem. 2002, 3, 167-173.

(32) Jahnke, W.; Florsheimer, A.; Blommers, M. J.; Paris, C. G.; Heim, J.; Nalin, C.M.; Perez, L. B. Second-site NMR screening and linker design. Curr. Top. Med. Chem. 2003, 3, 69-80.

(33) Vazquez, J.; Tautz, L.; Ryan, J. J.; Vuori, K.; Mustelin, T.; Pellecchia, M. Development of molecular probes for second-site screening and design of protein tyrosine phosphatase inhibitors. J. Med. Chem. 2007, 50, 2137-2143. 
(34) Vazquez, J.; De, S. K. ; Chen, L. H.; Riel-Mehan, M.; Emdadi, A.; Cellitti, J.; Stebbins, J. L.; Rega, M. F.; Pellecchia, M. Development of paramagnetic probes for molecular recognition studies in protein kinases. J. Med. Chem. 2008, $51,3460-3465$.

(35) Egger, J.; Weckerle, C.; Cutting, B.; Schwardt, O.; Rabbani, S.; Lemme, K.; Ernst, B. Nanomolar E-selectin antagonists with prolonged half-lives by a fragment-based approach. J. Am. Chem. Soc. 2013, 135, 9820-9828.

(36) Cheng, Y.; Judd, T. C.; Bartberger, M. D.; Brown, J.; Chen, K.; Fremeau, R. T. Jr.; Hickman, D.; Hitchcock, S. A.; Jordan, B.; Li, V.; Lopez, P.; Louie, S. W.; Luo, Y.; Michelsen, K.; Nixey, T.; Powers, T. S.; Rattan, C.; Sickmier, E. A.; St Jean, D. J. Jr.; Wahl, R. C.; Wen, P. H.; Wood, S. From fragment screening to in vivo efficacy: optimization of a series of 2-aminoquinolines as potent inhibitors of beta-site amyloid precursor protein cleaving enzyme 1 (BACE1). J. Med. Chem. 2011, 54, 5836-5857.

(37) Jordan, J. B.; Whittington, D. A.; Bartberger, M. D.; Sickmier, E. A.; Chen, K.; Cheng, Y.; Judd, T. A fragmentlinking approach using 19F NMR spectroscopy to obtain highly potent and selective inhibitors of $\beta$-secretase. J. Med. Chem. 2016, 59, 3732-3749.

(38) Casale, E.; Amboldi, N.; Brasca, M. G.; Caronni, D.; Colombo, N.; Dalvit, C.; Felder, E. R.; Fogliatto, G.; Galvani, A.; Isacchi, A.; Polucci, P.; Riceputi, L.; Sola, F.; Visco, C.; Zuccotto, F.; Casuscelli, F. Fragment-based hit discovery and structure-based optimization of aminotriazoloquinazolines as novel HSP90 inhibitors. Bioorg. Med. Chem. 2014, $22,4135-4150$.

(39) Kohlmann, A.; Zech, S. G.; Li, F.; Zhou, T.; Squillace, R. M.; Commodore, L.; Greenfield, M. T.; Lu, X.; Miller, D. P.; Huang, W. S.; Qi, J.; Thomas, R. M.; Wang, Y.; Zhang, S.; Dodd, R.; Liu, S.; Xu, R.; Xu, Y.; Miret, J. J.; Rivera, V.; Clackson, T.; Shakespeare, W. C.; Zhu, X.; Dalgarno, D. C. Fragment growing and linking lead to novel nanomolar lactate dehydrogenase inhibitors. J. Med. Chem. 2013, 56, 1023-1040.

(40) Erlanson, D. A.; Braisted, A. C.; Raphael, D. R.; Randal, M.; Stroud, R. M.; Gordon, E. M.; Wells, J. A. Site-directed ligand discovery. Proc. Natl. Acad. Sci. U.S.A. 2000, 97, 9367-9372.

(41) Erlanson, D. A.; Lam, J. W.; Wiesmann, C.; Luong, T. N.; Simmons, R. L.; DeLano, W. L.; Choong, I. C.; Burdett, M. T.; Flanagan, W. M.; Lee, D.; Gordon, E. M.; O'Brien T. In situ assembly of enzyme inhibitors using extended tethering. Nat. Biotechnol. 2003, 21, 308-314.

(42) Braisted, A. C.; Oslob, J. D.; Delano, W. L.; Hyde, J.; McDowell, R. S.; Waal, N.; Yu, C.; Arkin, M. R.; Raimundo, B. C. Discovery of a potent small molecule IL-2 inhibitor through fragment assembly. J. Am. Chem. Soc. 2003, 125, 3714-3715.

(43) Ward, R. A.; Brassington, C.; Breeze, A. L.; Caputo, A.; Critchlow, S.; Davies, G.; Goodwin, L.; Hassall, G.; Greenwood, R.; Holdgate, G. A.; Mrosek, M.; Norman, R. A.; Pearson, S.; Tart, J.; Tucker, J. A.; Vogtherr, M.; Whittaker, D.; Wingfield, J.; Winter, J.; Hudson, K. Design and Synthesis of novel lactate dehydrogenase A inhibitors by fragment-based lead generation. J. Med. Chem. 2012, 55, 3285-3306. 
(44) Möbitz, H.; Machauer, R.; Holzer, P.; Vaupel, A.; Stauffer, F.; Ragot, C.; Caravatti, G.; Scheufler, C.; Fernandez, C.; Hommel, U.; Tiedt, R.; Beyer, K. S.; Chen, C.; Zhu, H.; Gaul, C. The discovery of potent, selective and structurally novel DOT1L inhibitors by a fragment linking approach. ACS Med. Chem. Lett. 2017, 8, 338-343.

(45) Howard, N.; Abell, C.; Blakemore, W.; Chessari, G.; Congreve, M.; Howard, S.; Jhoti, H.; Murray, C. W.; Seavers, L. C.; van Montfort, R. L. Application of fragment screening and fragment linking to the discovery of novel thrombin inhibitors. J. Med. Chem. 2006, 49, 1346-1355.

(46) Barker, J. J.; Barker, O.; Courtney, S. M.; Gardiner, M.; Hesterkamp, T.; Ichihara, O.; Mather, O.; Montalbetti, C. A.; Müller, A.; Varasi, M.; Whittaker, M.; Yarnold, C. J. Discovery of a novel HSP90 inhibitor by fragment linking. ChemMedChem. 2010, 5, 1697-1700.

(47) Ahmed-Belkacem, A.; Colliandre, L.; Ahnou, N.; Nevers, Q.; Gelin, M.; Bessin, Y.; Brillet, R.; Cala, O.; Douguet, D.; Bourguet, W.; Krimm, I.; Pawlotsky, J. M.; Guichou, J. F. Fragment-based discovery of a new family of nonpeptidic small-molecule cyclophilin inhibitors with potent antiviral activities. Nat. Commun. 2016, 7, 12777.

(48) Benmansour, F.; Trist, I.; Coutard, B.; Decroly, E.; Querat, G.; Brancale, A.; Barral, K. Discovery of novel dengue virus NS5 methyltransferase non-nucleoside inhibitors by fragment-based drug design. Eur. J. Med. Chem. 2017, $125,865-880$.

(49) Hernandez, J.; Hoffer, L.; Coutard, B.; Querat, G.; Roche, P.; Morelli, X.; Decroly, E.; Barral, K. Optimization of a fragment linking hit toward Dengue and Zika virus NS5 methyltransferases inhibitors. Eur. J. Med. Chem. 2019, $161,323-333$.

(50) Brear, P.; De Fusco, C.; Hadje Georgiou, K.; Francis-Newton, N. J.; Stubbs, C. J.; Sore, H. F.; Venkitaraman, A. R.; Abell, C.; Spring, D. R.; Hyvönen, M. Specific inhibition of CK2 $\alpha$ from an anchor outside the active site. Chem. Sci. 2016, 7, 6839-6845.

(51) De Fusco, C.; Brear, P.; Iegre, J.; Georgiou, K. H.; Sore, H. F.; Hyvönen, M.; Spring, D. R. A fragment-based approach leading to the discovery of a novel binding site and the selective CK2 inhibitor CAM4066. Bioorg. Med. Chem. 2017, 25, 3471-3482.

(52) Iegre, J.; Brear, P.; De Fusco, C.; Yoshida, M.; Mitchell, S. L.; Rossmann, M.; Carro, L.; Sore, H. F.; Hyvönen, M.; Spring, D. R. Second-generation CK2 $\alpha$ inhibitors targeting the $\alpha$ D pocket. Chem. Sci. 2018, 9, 3041-3049.

(53) Frank, A. O.; Feldkamp, M. D.; Kennedy, J. P.; Waterson, A. G.; Pelz, N. F.; Patrone, J. D.; Vangamudi, B.; Camper, D. V.; Rossanese, O. W.; Chazin, W. J.; Fesik, S. W. Discovery of a potent inhibitor of replication protein A proteinprotein interactions using a fragment-linking approach. J. Med. Chem. 2013, 56, 9242-9250.

(54) Swayze, E. E.; Jefferson, E. A.; Sannes-Lowery, K. A.; Blyn, L. B.; Risen, L. M.; Arakawa, S.; Osgood, S. A.; Hofstadler, S. A.; Griffey, R. H. SAR by MS: a ligand based technique for drug lead discovery against structured RNA targets. J. Med. Chem. 2002, 45, 3816-3819.

(55) Green, N. M. Avidin. Adv. Protein Chem. 1975, 29, 85-133. 
(56) Maly, D. J.; Choong, I. C.; Ellman, J. A. Combinatorial target-guided ligand assembly: identification of potent subtype-selective c-SRC inhibitors. Proc. Natl. Acad. Sci. U.S.A. 2000, 97, 2419-2424.

(57) Huc, I.; Lehn, J. M. Virtual combinatorial libraries: Dynamic generation of molecular and supramolecular diversity by self-assembly. Proc. Natl. Acad. Sci. U.S.A. 1997, 94, 2106-2110.

(58) Hochgürtel, M.; Kroth, H.; Piecha, D.; Hofmann, M. W.; Nicolau, C.; Krause, S.; Schaaf, O.; Sonnenmoser, G.; Eliseev, A. V. Target-induced formation of neuraminidase inhibitors from in vitro virtual combinatorial libraries. Proc. Natl Acad. Sci. U.S.A. 2002, 99, 3382-3387.

(59) Hochgürtel, M.; Biesinger, R.; Kroth, H.; Piecha, D.; Hofmann, M. W.; Krause, S.; Schaaf, O.; Nicolau, C.; Eliseev, A. V. Ketones as building blocks for dynamic combinatorial libraries: highly active neuraminidase inhibitors generated via selection pressure of the biological target. J. Med. Chem. 2003, 46, 356-358.

(60) Mondal, M.; Radeva, N.; Köster, H.; Park, A.; Potamitis, C.; Zervou, M.; Klebe, G.; Hirsch, A. K. Structure-based design of inhibitors of the aspartic protease endothiapepsin by exploiting dynamic combinatorial chemistry. Angew. Chem. Int. Ed. Engl. 2014, 53, 3259-3263.

(61) Congreve, M. S.; Davis, D. J.; Devine, L.; Granata, C.; O'Reilly, M.; Wyatt, P. G.; Jhoti, H. Detection of ligands from a dynamic combinatorial library by X-ray crystallography. Angew. Chem. Int. Ed. Engl. 2003, 42, 4479-4482.

(62) Schmidt, M. F.; El-Dahshan, A.; Keller, S.; Rademann, J. Selective identification of cooperatively binding fragments in a high-throughput ligation assay enables development of a picomolar caspase-3 inhibitor. Angew. Chem. Int. Ed. Engl. 2009, 48, 6346-6349.

(63) Jaegle, M.; Steinmetzer, T.; Rademann, J. Protein-templated formation of an inhibitor of the blood coagulation factor Xa through a background-free amidation reaction. Angew. Chem. Int. Ed. Engl. 2017, 56, 3718-3722.

(64) Lewis, W. G.; Green, L. G.; Grynszpan, F.; Radić, Z.; Carlier, P. R.; Taylor, P.; Finn, M. G.; Sharpless, K. B. Click chemistry in situ: acetylcholinesterase as a reaction vessel for the selective assembly of a femtomolar inhibitor from an array of building blocks. Angew. Chem. Int. Ed. Engl. 2002, 41, 1053-1057.

(65) Suzuki, T.; Ota, Y.; Kasuya, Y.; Mutsuga, M.; Kawamura, Y.; Tsumoto, H.; Nakagawa, H.; Finn, M. G.; Miyata, N. An unexpected example of protein-templated click chemistry. Angew. Chem. Int. Ed. Engl. 2010, 49, 6817-6820.

(66) Hirose, T.; Maita, N.; Gouda, H.; Koseki, J.; Yamamoto, T.; Sugawara, A.; Nakano, H.; Hirono, S.; Shiomi, K.; Watanabe, T.; Taniguchi, H.; Sharpless, K. B.; Omura, S.; Sunazuka, T. Observation of the controlled assembly of preclick components in the in situ click chemistry generation of a chitinase inhibitor. Proc. Natl. Acad. Sci. U.S.A. 2013, 110, 15892-15897.

(67) Mondal, M.; Unver, M. Y.; Pal, A.; Bakker, M.; Berrier, S. P.; Hirsch, A. K. H. Fragment-based drug design facilitated by protein-templated click chemistry: fragment linking and optimization of inhibitors of the aspartic protease endothiapepsin. Chem. Eur. J. 2016, 22, 14826-14830.

(68) Hu, X.; Sun, J.; Wang, H. G.; Manetsch, R. Bcl-X $\mathrm{X}_{\mathrm{L}}$-templated assembly of its own protein-protein interaction modulator from fragments decorated with thio acids and sulfonyl azides. J. Am. Chem. Soc. 2008, 130, 13820-13821. 
(69) Kulkarni, S. S.; Hu, X.; Doi, K.; Wang, H. G.; Manetsch, R. Screening of protein-protein interaction modulators via sulfo-click kinetic target-guided synthesis. ACS Chem. Biol. 2011, 6, 724-723.

(70) Chen, H.; Zhou, X.; Wang, A.; Zheng, Y.; Gao, Y.; Zhou, J. Evolutions in fragment-based drug design : the deconstruction-reconstruction approach. Drug Discov. Today. 2015, 20, 105-113.

(71) Mousnier, A.; Bell, A. S.; Swieboda, D. P.; Morales-Sanfrutos, J.; Pérez-Dorado, I.; Brannigan, J. A.; Newman, J.; Ritzefeld, M.; Hutton, J. A.; Guedán, A.; Asfor, A. S.; Robinson, S. W.; Hopkins-Navratilova, I.; Wilkinson, A. J.; Johnston, S. L.; Leatherbarrow, R. J.; Tuthill, T. J.; Solari, R.; Tate, E. W. Fragment-derived inhibitors of human Nmyristoyltransferase block capsid assembly and replication of the common cold virus. Nat. Chem. 2018, 10, 599606.

(72) Taylor, S. J.; Padyana, A. K.; Abeywardane, A.; Liang, S.; Hao, M. H.; De Lombaert, S.; Proudfoot, J.; Farmer, B. S. 3rd.; Li, X.; Collins, B.; Martin, L.; Albaugh, D. R.; Hill-Drzewi, M.; Pullen, S. S.; Takahashi, H. Discovery of potent, selective chymase inhibitors via fragment linking strategies. J. Med. Chem. 2013, 56, 4465-4481.

(73) Davidson, A.; Begley, D. W.; Lau, C.; Varani, G. A small molecule probe induces a conformation in HIV TAR RNA capable of binding drug-like fragments. J. Mol. Biol. 2011, 410, 984-996.

(74) Pang, Y. P.; Quiram, P.; Jelacic, T.; Hong, F.; Brimijoin, S. Highly potent, selective, and low cost bistetrahydroaminacrine inhibitors of acetylcholinesterase. Steps toward novel drugs for treating Alzheimer's disease. J. Biol. Chem. 1996, 271, 23646-23649.

(75) Surade, S.; Nancy, T. Y.; Hengrung, N.; Lechartier, B.; Cole, S. T.; Abell, C.; Blundell, T. L. A structure-guided fragment-based approach for the discovery of allosteric inhibitors targeting the lipophilic binding site of transcription factor EthR. Biochem. J. 2014, 458, 387-394.

(76) Trapero, A.; Pacitto, A.; Singh, V.; Sabbah, M.; Coyne, A. G.; Mizrahi, V.; Blundell, T. L.; Ascher, D. B.; Abell, C. A fragment-based approach to targeting inosine-5'-monophosphate dehydrogenase (IMPDH) from Mycobacterium tuberculosis. J. Med. Chem. 2018, 61, 2806-2822.

(77) Burgess, L. E.; Newhouse, B. J.; Ibrahim, P.; Rizzi, J.; Kashem, M. A.; Hartman, A.; Brandhuber, B. J.; Wright, C. D.; Thomson, D. S.; Vigers, G. P.; Koch, K. Potent selective nonpeptidic inhibitors of human lung tryptase. Proc. Natl. Acad. Sci. U.S.A. 1999, 96, 8348-8352.

(78) Matsui, Y.; Yasumatsu, I.; Asahi, T.; Kitamura, T.; Kanai, K.; Ubukata, O.; Hayasaka, H.; Takaishi, S.; Hanzawa, H.; Katakura, S. Discovery and structure-guided fragment-linking of 4-(2,3-dichlorobenzoyl)-1-methyl-pyrrole-2carboxamide as a pyruvate kinase M2 activator. Bioorg. Med. Chem. 2017, 25, 3540-3546.

(79) Drapier, T.; Geubelle, P.; Bouckaert, C.; Nielsen, L.; Laulumaa, S.; Goffin, E.; Dilly, S.; Francotte, P.; Hanson, J.; Pochet, L.; Kastrup, J.; Pirotte, B. Enhancing action of positive allosteric modulators through the design of dimeric compounds. J. Med. Chem. 2018, 61, 5279-5291.

(80) Sun, Q.; Phan, J.; Friberg, A. R.; Camper, D. V.; Olejniczak, E. T.; Fesik, S. W. A method for the second-site screening of K-Ras in the presence of a covalently attached first-site ligand. J. Biomol. NMR. 2014, 60, 11-14. 
